\title{
A critical review of biogas production and usage with legislations framework across the globe
}

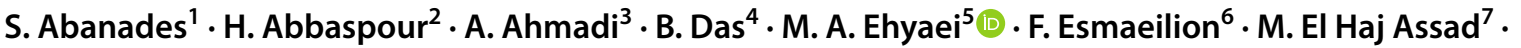 \\ T. Hajilounezhad ${ }^{8}$. D. H. Jamali ${ }^{9}$ A. Hmida ${ }^{10}$ H. A. Ozgoli ${ }^{11}$-S. Safari ${ }^{12}$ - M. AlShabi ${ }^{13}$ - E. H. Bani-Hani ${ }^{14}$
}

Received: 10 September 2020 / Revised: 25 March 2021 / Accepted: 30 March 2021 / Published online: 16 May 2021

(c) Islamic Azad University (IAU) 2021

\begin{abstract}
This review showcases a comprehensive analysis of studies that highlight the different conversion procedures attempted across the globe. The resources of biogas production along with treatment methods are presented. The effect of different governing parameters like feedstock types, pretreatment approaches, process development, and yield to enhance the biogas productivity is highlighted. Biogas applications, for example, in heating, electricity production, and transportation with their global share based on national and international statistics are emphasized. Reviewing the world research progress in the past 10 years shows an increase of 90\% in biogas industry (120 GW in 2019 compared to $65 \mathrm{GW}$ in 2010). Europe (e.g., in 2017) contributed to over 70\% of the world biogas generation representing 64 TWh. Finally, different regulations that manage the biogas market are presented. Management of biogas market includes the processes of exploration, production, treatment, and environmental impact assessment, till the marketing and safe disposal of wastes associated with biogas handling. A brief overview of some safety rules and proposed policy based on the world regulations is provided. The effect of these regulations and policies on marketing and promoting biogas is highlighted for different countries. The results from such studies show that Europe has the highest promotion rate, while nowadays in China and India the consumption rate is maximum as a result of applying up-to-date policies and procedures.
\end{abstract}

Keywords Application $\cdot$ Biogas $\cdot$ Electricity $\cdot$ Heating

Editorial responsibility: Jing Chen.

M. A. Ehyaei

aliehyaei@yahoo.com

1 Processes, Materials, and Solar Energy Laboratory, PROMES-CNRS, 7 Rue du Four Solaire, 66120 Font-Romeu, France

2 Department of Biology, Faculty of Biological Science, North Tehran Branch, Islamic Azad University, Tehran, Iran

3 School of New Technologies, Iran University of Science \& Technology, Tehran, Islamic Republic of Iran

4 Department of Mechanical Engineering, National Institute of Technology Silchar, Silchar, Asaam 788010, India

5 Department of Mechanical Engineering, Pardis Branch, Islamic Azad University, Pardis New City, Iran

6 Department of Energy Systems Engineering, School of Advance Technologies, Iran University of Science \& Technology (IUST), Tehran, Iran

7 Sustainable \& Renewable Energy Engineering Department, University of Sharjah, Sharjah, United Arab Emirates
8 Department of Mechanical \& Aerospace Engineering, University of Missouri, Columbia, MO, USA

9 School of Environment, College of Engineering, University of Tehran, Tehran, Iran

10 R, L. Applied Thermodynamic, National Engineering School of Gabes, University of Gabes, Gabes, Tunisia

11 Department of Mechanical Engineering, Iranian Research Organization for Science and Technology (IROST), Sh. Ehsani Rad St., Enqelab StParsa SqAhmadabad Mostoufi RdAzadegan Highway, 3313193685 Tehran, Iran

12 Department of Energy Engineering, Faculty of Natural Resources and Environment, Science and Research Branch, Islamic Azad University (IAU), Daneshgah Blvd, Simon Bolivar Blvd, 1477893855 Tehran, Iran

13 Department of Mechanical and Nuclear Engineering, University of Sharjah, Sharjah, UAE

14 Department of Mechanical Engineering, School of Engineering, Australian College of Kuwait, Kuwait City, Kuwait 


$\begin{array}{ll}\text { Abbreviations } \\ \text { AcoD } & \text { Anaerobic co-digestion } \\ \text { AD } & \text { Anaerobic digestion } \\ \text { ATR } & \text { Autothermal reforming } \\ \text { AnMBR } & \text { Anaerobic membrane bioreactor } \\ \text { BAT } & \text { Best available techniques } \\ \text { BEP } & \text { Best environmental practices } \\ \text { BSR } & \text { Biogas steam reforming } \\ \text { CHP } & \text { Combined heat and power } \\ \text { CNG } & \text { Compressed natural gas } \\ \text { COD } & \text { Chemical oxygen demand } \\ \text { COVID-19 } & \text { Coronavirus disease of 2019 } \\ \text { EBA } & \text { European Biogas Association } \\ \text { EGSB } & \text { Expanded granular sludge blanket } \\ \text { EIA } & \text { Environmental impact assessment } \\ \text { FCV } & \text { Fuel cell vehicle } \\ \text { FTS } & \text { Fischer-Tropsch synthesis } \\ \text { GHG } & \text { Greenhouse gas } \\ \text { GT } & \text { Gas turbine } \\ \text { GTZ } & \text { German Technical Cooperation Agency } \\ \text { HTPT } & \text { Hydrothermal pretreatment } \\ \text { ICEs } & \text { Internal combustion engine } \\ \text { IREA } & \text { International Renewable Energy Agency } \\ \text { JICA } & \text { Japan international Cooperation agency } \\ \text { LBG } & \text { Liquefied biogas } \\ \text { LTFP } & \text { Lower-temperature fast pyrolysis } \\ \text { MARA } & \text { Ministry of Agriculture and Rural Affairs } \\ \text { MBR } & \text { Membrane bio-reactor } \\ \text { MEE } & \text { Ministry of Ecology and Environment } \\ \text { MF } & \text { Ministry of Finance } \\ \text { NDRC } & \text { National Development and Reform } \\ & \text { Commission } \\ \text { NGOs } & \text { Non-governmental organizations } \\ \text { NGV } & \text { Natural gas vehicles } \\ \text { OFMSW } & \text { Organic fraction of municipal solid waste } \\ \text { PSA } & \text { Pressure swing adsorption } \\ \text { RD } & \text { Research and development } \\ \text { RNG } & \text { Renewable natural gas } \\ \text { SC } & \text { State council } \\ \text { SOFC } & \text { Solid oxide fuel cells } \\ \text { TPAD } & \text { Thermal phased AD } \\ \text { USAID } & \text { United States Agency for International } \\ \text { VPSA } & \text { Development } \\ \text { VOC } & \text { Vacuum pressure swing adsorption } \\ \text { WBA } & \text { Volatile organic compound } \\ \text { WTE } & \text { World Biogas Association } \\ \text { WWTP } & \text { Waste-to-energy } \\ & \end{array}$

\section{Introduction}

From the 1980s onward, the striking jump in global energy consumption has been largely driven through fossil energy resources. Generally, oil, coal, natural gas, electricity, nuclear energy, and renewable energies have shared 33, 27, $24,7,4$, and $4 \%$ of total primary energy proportion in the whole world in 2018, respectively. Approximately, $85 \%$ of the world's primary energy consumption has been supplied by fossil fuels in 2018 (BP. 2019; Ghasemian et al.2020).

The conversion of biomass to energy has been promoting from $65 \mathrm{GW}$ in 2010 to $120 \mathrm{GW}$ in 2019 due to climate change, reasonable energy prices, distributed generation increase, and environmental aspects, in recent years. Wastes with high moisture content are more compatible with conversion by anaerobic digestion, landfill, and digestion technologies. The global amount of biogas plant capacity was about $19.5 \mathrm{GW}$ at the end of 2019. Organic wastes are the most common feedstocks to produce biogas from wastes, including domestic wastes (food, fruits, and vegetables) or public moist wastes (cafes and restaurants, daily markets, and companies' biological wastes), due to significant moisture content and high degradability. These input materials are classified as OFMSW, which represents the organic fraction of municipal solid waste (Antoine Beylot et al. 2018; A. Luca C.R. 2015).

Biogas is inherently renewable, on the contrary to fossil fuels, because it is generated from biomass, and this source is practically a reserve of the solar energy via photosynthesis process. Anaerobic digestion (AD) biogas will not only enhance a country's energy basket status but also contribute significantly in conserving natural resources and protecting the environment (Teodorita Al Seadi DR 2008).

Biogas is naturally composed of biogenic material. This biogas, which occurs naturally, spreads into the ambient, and its major component, methane, plays a serious detrimental role in global warming (Bochmann and Montgomery 2013). Methane has been used as important fossil fuel and converted to generate power, transportation, and heating, over the past decades. Nowadays, the major portion of methane consumption and utilization comes from natural gas resources, but the production of bio-methane from waste recovery approaches has been meaningfully increased. Its production potential has been improved by $4 \%$ over 9 years (from 2010 to 2018). At present, about 3.5 Mtoe of biomethane is produced around the world and the potential for biomethane production today is over 700 Mtoe (Edenhofer et al. 2011). Of course, this does not mean that methane conversion is feasible from all kinds of natural resources. In other words, infrastructures for biogas development extremely rely on specific equipment 
and the availability of control and management systems. Therefore, a sustainable industry can be installed and implemented to generate bio-energy from renewable and green natural resources (Bochmann and Montgomery 2013).

Developed countries use advanced large-scale plants for utilizing biogas. Biogas is regularly applied to generate heat, power, and electricity. Also, several industrial applications for its utilization in biogas plants as a substitute to natural gas are being progressed. Based on the analyzed data, a continuous increase in biogas production has been observed due to the global policies and programs. Since $0.5 \%$ proportion of renewable energies contribution that is about $12.8 \mathrm{GW}$ (IRENA RES. 2015) is supposed to be achieved in 2020 for transportation sectors, bio-fuel production has been considered as the main source of this plan in different regions. It is noteworthy that biogas production should not be developed as a food production threat. For this reason, biofuels are mainly generated from cellulosic and lignin wastes (Nicolae Scarlat and Fahl 2018; Angelidaki et al. 2018).

A wide global market of biogas has been conspicuously promoted for the previous decades in various countries. Moreover, the advanced biogas production technologies have been supported by domestic or international supportive rules, such as research, design, and development (RD\&D) financial funds, subsidization, and guaranteed electricity purchase contracts to make a competitive market against conventional energy suppliers (Teodorita Al Seadi DR 2008).

According to Fig. 1, the different utilizations of the biogas technology offer a multi-purpose solution to generate the required energy of the industrial or social sectors. Biogas is mainly consumed for combined heat and power (CHP) plants, hydrogen production units, and advanced energy systems such as fuel cells.
Generally, in the European Union (EU) and North America (NA), biogas plants came to be developed more than in other continents for the last 40 years. The main advantages of the units located in the mentioned regions are industrial scale, energy efficiency, and high complexity level. Biogas production was considered by academic centers and governments owing to its potential in response to different global challenges. It should also be pointed out that using biogas technologies allows industries to eliminate greenhouse gases (GHGs) emissions and waste disposal pollutions, while it provides a broad spectrum of energy utilization such as heat, electricity, and transportation purposes, based on its renewable nature.

There are various strategies around the world for producing biogas from agricultural products. In Germany, for example, the production of cheap agricultural products that require low processing (with no outcomes for consumers) provides feedstock for biogas plants. New policies recommend the use of crops and plant residents, life stocks remaining, and landfill use (IRENA RES. 2015).

This review focuses on proposing a comprehensive analysis of the recent biogas technologies progress, aiming advances toward wastes conversion to produce electricity, heat, and other forms of energy carriers. It reports the current and future AD conversion technologies, as well as examines accessible details in the literature about feedstock categories, pretreatment approaches, process development, and its yield to increase production efficiency. Furthermore, suggested future biogas application trends and directions for efficient ways of energy generation from wastes are other main outputs of this study. Also, the present review highlights the emerging biogas technologies which are promoted to distribute biomethane and biofuel production, especially the production of hydrogen from biogas is the innovative insight in the mentioned field.
Fig. 1 Overview of biogas utilization

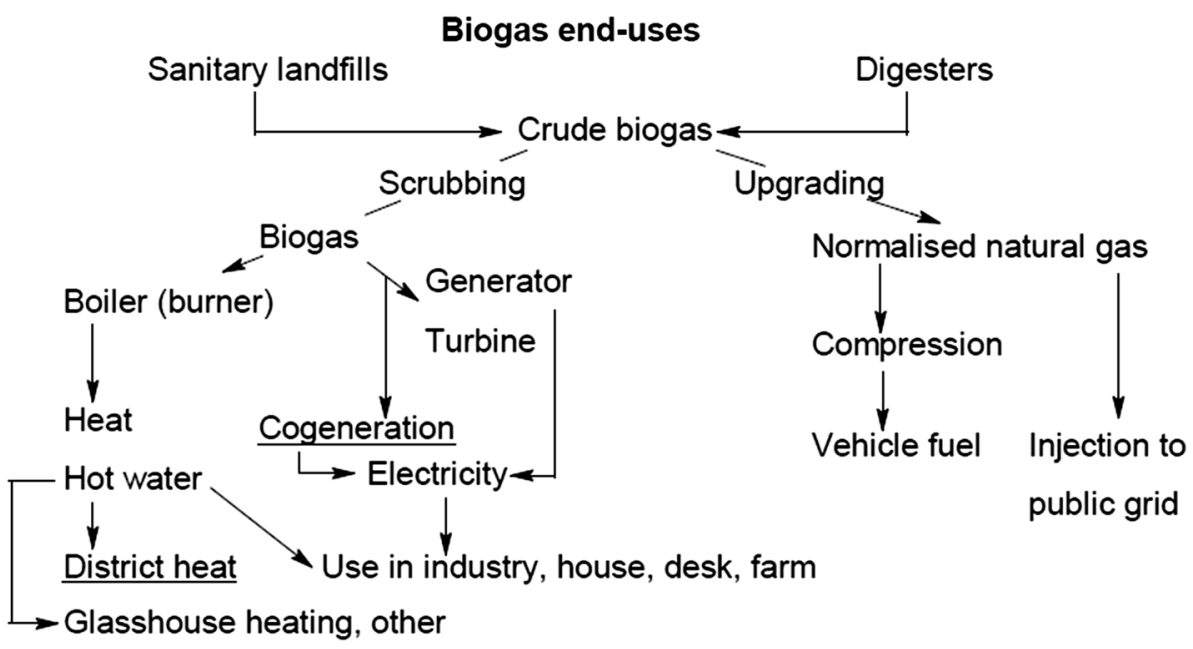

Springer 
The structure of the present research is as follows: "Biogas Applications" reports extensive data on the upto-date status of biogas consumption in energy generation, energy storage, and transportation. Biogas development levels around the world, regulations, and historical progress are expressed in "Biogas utilization in various parts of the world" section. Also, the characterization of the feedstocks and additives, pretreatment, process types, and related techniques are described in "Recent progress in biogas production" section. The novel technologies are indicated with their advantages and constraints for each section. Eventually, the conclusion and predictive tendencies for future research are explained in the last section.

Thus, this work represents a comprehensive review of the biogas in terms of a renewable energy source for both production and applications. The procedures for production and applications are up to date. Researchers' work in 2020 is presented where they used the most updated technologies which help other research agencies to continue from this end. The review of the development of the biogas industry and utilization covers 20 years of information. Moreover, a review of the international recent policies and regulations relevant to biogas management is provided. Based on that, a suggested policy based on international guidelines and international conventions is proposed.

\section{Methodology}

Published research papers and data on biogas sources, production, and applications are collected from the literature. These sources cover the years from 1997 till 2020 to summarize the current situation and development relevant to biogas. A review of policies and regulations on national and international levels is presented. Regulatory entities in the world that issue guidelines instruction to organize the biogas market are presented. This review showed the increase of world awareness regarding this source of energy by introducing the most updated policies in many countries. Based on all of the above, a proposed framework and policy is presented.

An introduction shows the necessity of biogas as a source of renewable energy is presented. The increasing demand for biogas in the energy section showed to be increased in the coming years. Biogas production process and the sources to get the biogas are presented. The sources vary from agricultural to animal wastes which are the richest biogas sources however, other sources such as wastewater treatment plants, and landfill disposal sites.

Applications of biogas and its contribution to the total national energy sector are presented. These applications range from energy conversion, producing alternative fuels, electricity generation, etc. Traditional methods of biogas production are presented with developments of such methods. New technologies and methods for production and purification of biogas are described.

\section{Biogas applications}

Biogas is globally considered as traditional off-grid energy. Biogas can also be utilized to generate electricity. The various applications of biogas are described below.

\section{Electricity generation}

Power generation from biomass is currently the most popular and growing market worldwide, due to technological improvements, decreasing reliance on fossil-based energy, and reduction of greenhouse gases (GHG) emissions. Biogas has the potential for electricity generation in power plants by internal combustion engines (ICEs) or gas turbines (GTs) as the two most commonly used power generation methods. Micro gas turbines are also an attractive method due to lower NOx emissions and flexibility to meet various load requirements. Multiple microturbines sizing from $70 \mathrm{~kW}$ to over $250 \mathrm{~kW}$ can be employed to meet low/medium power load demands. The electricity can provide the required power to the adjacent industries and companies. With the development of electric cars, another state-of-the-art application, especially in developed countries like Germany, is the utility of electricity for e-vehicles of a connected car-sharing association (Scarlat et al. 2018).

The major benefit of on-site electricity generation is to prevent transport losses and to increase reliability due to the independence from a centralized grid mostly run by traditional fossil fuels. It also brings extra economical profit by providing the required in-house power demand and selling the extra electricity (Scarlat et al. 2018).

\section{Heat generation}

Biogas can be directly combusted in boilers for heat generation only. It is feasible to slightly modify natural gas boilers to operate with biogas. As farm biomass is a major biogas production source, the generated heat can be used for heating the digesters, farm buildings like housing units for pigs/sties, greenhouses, as well as aquafarming, cooling/refrigeration of farm products, and drying purposes. The drying process in agricultural businesses, such as drying of digestate, woodchip, grain, herbs, and spices, is a remarkable added value to the farm economy (Herbes et al. 2018).

Available heat for external use, representing nearly $30-50 \%$ of generated heat, can be sold to a nearby district to be used for district heating/cooling like heating swimming pools. Also, an absorption chiller can be a potential candidate to better use heat through CHP, in addition to 
cooling power (tri-generation). It can convert heat into cooling power with high efficiencies of up to $70 \%$ (Rümmeli et al. 2010).

\section{Combined heat and power (CHP) generation}

Concurrent generation of heat and electricity by CHP systems is an operational approach to upgrade the energy conversion efficiency of biogas. When only converting biogas to electricity or heat, just a minor fraction of energy contained in biogas is used. Characteristically, in these types of systems, associated power conversion productivity is somewhere in the region of 30 to $40 \%$, while it is diminished by employing biogas as an alternative for refined and purely natural gas (Saadabadi et al. 2019).

CHP plants offer the advantage of high-temperature exhaust gas from the electricity generation subsystem (ICEs or GTs) as a source of valuable heat for many heating purposes already discussed before. Although the electricity generation efficiency of simple plants is only $20-45 \%$ (Muche et al. 2016), a larger portion of energy (around 60\% of the utilized energy (Damyanova and Beschkov 2020)) is converted to heat that is reused by heat recovery systems; making it more attractive when there is a high heat demand. This considerably enhances the system efficiency and improves the payback period of plants, making the distributed generation the most common biogas application. The extra electricity could be supplied for the national grid and the extra heat can be sold to the local district utilization.

A CHP cycle has sufficient productivity that has an efficiency up to $90 \%$, while it can produce $35 \%$ and $65 \%$ of the generated electricity and heat, respectively. In this case, some thermal energy is used to heat the process and about $2 / 3$ is used for external uses. In some proposed models for biogas-based power plants, the use of generated heat is ignored and the focus is only on generating electricity. Without any doubt, this approach has no economic justification and must use all its thermal potential.

There are three common ways to produce heat and power from biogas including Gas-Otto engines, Pilot-injection gas motor, and Sterling motors (Teodorita Al Seadi DR 2008). In EU, four-stroke engines and ignition oil diesel engines contributed roughly the same in CHPs at somewhere in the vicinity of 50\%, each (Dieter Deublein 2008). Biogas is also employed in gas turbines, microturbines, and fuel cells (discussed in detail in "Fuel cells" section ) for CHP applications (Kaparaju and Rintala 2013; Nikpey Somehsaraei et al. 2014).

CHP plants offer the advantage of high-temperature exhaust gas from the electricity generation subsystem (ICEs or GTs) as a source of valuable heat for many heating purposes already discussed. Although the electricity generation efficiency of simple plants is only $20-45 \%$ (Muche et al.
2016), a larger portion of energy (around 60\% of the utilized energy (Damyanova and Beschkov 2020)) is converted to heat that is reused by heat recovery systems; making it more attractive when there is a high heat demand. This considerably enhances the system efficiency and improves the payback period of plants, making the distributed generation the most common biogas application. The extra electricity could be supplied for the national grid, and the extra heat can be sold to the local district utilization. Also, an absorption chiller can be a potential candidate to better use the extra heat through CHP, in addition to cooling power (tri-generation). It can convert heat into cooling with high efficiencies of up to $70 \%$ (Rümmeli et al. 2010).

A CHP cycle has sufficient productivity that has an efficiency up to $90 \%$, while it can produce $35 \%$ and $65 \%$ of the generated electricity and heat, respectively (Shipley et al. 2009). In some proposed models for biogas-based power plants, the use of generated heat is ignored and the focus is only on generating electricity. Without any doubt, this approach has no economic justification and must use all its thermal potential.

\section{Upgrading to biomethane}

If biogas is upgraded and purified to biomethane, it can be fed into natural gas grid to be used for heating purposes, power generation, or to provide fuel for compressed natural gas (CNG) and even natural gas vehicles (NGV). A significant benefit of biomethane is that it can be stored to meet peak demands (Herbes et al. 2018). The two major steps to produce biomethane are upgrading methane content up to 95-97\% followed by a cleaning process to eliminate water vapor, hydrogen sulfide, oxygen, ammonia, siloxanes, carbon dioxide, carbon monoxide, hydrocarbons, and nitrogen (Ryckebosch et al. 2011). Biogas upgrading is performed by physical and chemical technologies such as adsorption, absorption, cryogenic and membrane separations, and gas separation membranes as well as biological technologies (in situ and ex situ (Kapoor et al. 2019)). Although biological methods are emerging, suggesting an enormous technological potential, they are not widely used in industry since they are generally much slower, have low rates of reaction/synthesis, and require long startup period that made them less economically feasible, while physicochemical methods are common due to technological advancements and implementations (Scarlat et al. 2018).

Upgrading biogas to biomethane or renewable natural gas (RNG) is on a hot trend in developed countries especially in North America among oil and gas companies for decreasing GHG emissions and using the carbon credit. There are also other environmental and economical benefits in smaller scale to farmers, municipalities, and counties for waste management and profitable contracts with gas utility companies. 
Biomethane market for transportation purposes equaled to 160 cubic meter per year in 2015 Eurostat.European Statistics (2019).

\section{Transportation fuel}

Biogas converted to biomethane (through upgrading and cleaning) can be readily used in natural gas-powered vehicles as another option for fossil natural gas. Using biomethane as transportation fuel results in remarkably low GHG emissions that make it a suitable source of renewable fuel. Biomethane turns out to be a great fit to replace fossil-based fuels in terms of environmental and economic considerations (Scarlat et al. 2018). However, the overall efficiency is extremely improved when biomethane is utilized in advanced hybrid or fuel cell vehicles (FCVs) in comparison to current biodiesel or ethanol-powered ICE vehicles (Faaij 2006).

Generally, biogas can be improved to transportation fuels (bio-CNG) that can be stored for future use, in the form of liquefied biogas (LBG), syngas/hydrogen, methanol for gasoline production, ethanol, and higher alcohols (Yang et al. 2014). Compression and liquefaction are common physical methods to convert biogas into bio-CNG and LBG, while the dominant chemical approach to obtain syngas is catalytic reforming. If Fischer-Tropsch synthesis (FTS) or fermentation is employed, syngas may be converted into a variety of alcohols like methanol, ethanol, and butanol (Yang et al. 2014). This fuel alternative has already been applied within the European Union and the USA. As an example, many vehicles run on biogas in the urban public transport (in Sweden and Germany) either as $100 \%$ methane (CBG100) or mixed with natural gas (e.g., CBG10 and CBG50) (Damyanova and Beschkov 2020; Yang et al. 2014).

\section{Hydrogen production}

Hydrogen displays many promising potentials for renewable energy and the chemical industry due to its high potential for energy production. Hydrogen offers the biggest share of energy per unit mass $(121.000 \mathrm{~kJ} / \mathrm{kg})$. The hydrogen council suggests about $18 \%$ contribution of total final energy utilization by 2050 . Hydrogen is best employed in fuel cells as an emerging energy application to produce electricity, heat, and possibly water. Furthermore, there are many applications in chemical industries for hydrogen, including food treatment, hydrogenation methods, production of ammonia and methanol, Fischer-Tropsch synthesis, pharmaceutical manufacturing, among others (Armor 1999).

Technically, hydrogen $\left(\mathrm{H}_{2}\right)$ can be released from the BSR (biogas steam reforming) process. This process has temperature flexibility in the range of 600 to $1000^{\circ} \mathrm{C}$, which also includes catalytic techniques. (Holladay and J., King, D.L.,
Wang, Y. 2009; Alves and C.B., Niklevicz, R.R., Frigo, E.P., Frigo, M.S., Coimbra-Araújo, C.H. 2013). The main difference between BSR and SMR (steam methane reforming) is the presence of carbon dioxide in the feedstock. This factor increases the sensitivity to carbon production in the process. The produced carbon can deposit in the active phase of the catalyst to create deactivation.(Gioele Di Marcoberardino et al. 2018). Furthermore, fed gas can affect the hydrogen separation unit. In this case, PSA (pressure swing absorption) and VPSA (vacuum PSA) are the most common methods of purifying the system for hydrogen-rich reformate or syngas (Ugarte and P., Lasobras, J., Soler, J., Menéndez, M., Herguido, J. 2017; Ahn and Y.W., Lee, D.G., Kim, K.H., Oh, M., Lee, C.H. 2012). The potential of hydrogen production from all landfill sources in the USA is probably between the total potential of 16 million tons of methane from raw biogas and 4.2 million tons of hydrogen (Milbrandt GSaA. 2010). Biogas production systems have a capability for production from $100 \mathrm{Nm}^{3} / \mathrm{h}$ for small-scaled agricultural to a few $1000 \mathrm{Nm}^{3} / \mathrm{h}$ for large-scaled municipal waste landfills; furthermore, occasionally, not all biogas may be converted to the desired hydrogen and further biogas valorization can coexist in the system. Therefore, the capacity considered for BSR should be in the range of 50 and $1000 \mathrm{Nm}^{3} \mathrm{H}_{2} / \mathrm{h}$ (Doan Pham Minh et al. 2018).

Hydrogen is clean transportation fuel, while as discussed earlier syngas may be used as a feedstock for alcohol production. With new advancements in reforming procedures, biogas can now be directly improved to syngas by dry or steam reforming without the necessity to remove carbon dioxide (Yang et al. 2014).

\section{Fuel cells}

Fuel cells are probably the cutting-edge application of biogas. Recent advances in fuel cells resulting in low emissions $\left(\mathrm{CO}_{2}, \mathrm{NO}_{\mathrm{x}}\right)$ and high efficiency make them suitable for power generation and transportation purposes. Also, fuel cells can be utilized in large-scale power plants, power distribution generators, buildings, small-scaled and portable power supply apparatus for microelectronic equipment, and secondary power components in vehicles (Alves et al. 2013).

Fuel cells can use the chemical energy of hydrogen and oxygen without any intermediaries to deliver electricity and heat (A. Trendewicz R.B. 2013). In this case, there are only a small number of fuel cell-based power plants (most of which are pilots) that generate electrical power from biogas. (S. Ali Saadabadi ATT, Liyuan Fan, Ralph E.F. Lindeboom, Henri Spanjers, P.V. Aravind. 2019). Fuel cells exhibit high electrical efficiency of $60 \%$ (in power generation only mode) and thermal efficiency of up to $40 \%$ (in CHP applications) (Pöschl et al. 2010), but can easily be integrated with other power generation systems like gas turbines or microgas 
turbines to further improve their performance. Also, biogas fueled integrated solid oxide fuel cell (SOFC)-CHP offers a modern energy system that can address both heat and power generation demands for decentralized grids with drastically higher electrical efficiencies (Wongchanapai et al. 2013; Safari et al. 2020; Safari et al. 2020). Such high efficiency compared to other common combustion technologies is a result of not being limited by thermodynamic Carnot efficiency. SOFCs are more tolerant to fuel impurity and flexibility; hence offering better integration with biogas systems (Wasajja et al. 2020). This highlights their key role in enhancing the highly efficient generation of electricity from biogas, which demonstrates significant environmental and economic merits. However, for the use of biogas as fuel in fuel cells, a cleaning procedure seems essential to eliminate biogas impurities such as $\mathrm{H}_{2} \mathrm{~S}$, siloxanes, and other volatile organic compounds (VOCs) that have harmful impacts on fuel cell operation.

Furthermore, hydrogen produced from biogas can directly feed fuel cells. The reforming practice can be succeeded either internally employing fuel cells or externally by a catalytic pre-reformer. The three chief techniques for methane conversion are steam reforming, partial oxidation (POX), and dry reforming. Besides, mixed approaches like autothermal reforming (ATR) (mixed steam reforming and methane POX) are applicable. In a pilot plant constructed in Barcelona, Spain named "Biocell project", biogas from a WWTP was employed in two categories of a fuel cell. The first was proton-exchange membrane fuel cell (PEMFC) that entailed exterior gas cleaning and reforming unit. Biogas has also been added into a SOFC after the cleaning process. This pilot plant is intended for $2.8 \mathrm{kWe}$. Electrical and thermal effectiveness for the SOFC pilot plant was 24.2 and 39.4\%, respectively, which are considerably more than those for the PEMFC pilot plant (S. Ali Saadabadi ATT, Liyuan Fan, Ralph E.F. Lindeboom, Henri Spanjers, P.V. Aravind. 2019; Arespacochaga and CV, C. Peregrina, C. Mesa, L. Bouchy, J. Cortina 2015).

\section{Biogas development in various parts of the world}

The worldwide biogas industry has increased more than $90 \%$ between 2010 and 2018, while further growth is still expected. The International Renewable Energy Agency (IRENA) reported that the overall potential for the biogas industry in 2018 could provide 88 Tera Watt per hour (TWh) of biogas each year. Installed electricity generated from biogas reached $18.1 \mathrm{GW}$ in 2018 , against $8.2 \mathrm{GW}$ in 2009 (Agency 2019). Over 20\% of electricity produced in the entire biopowered production is generated from biogas, with a share of $4 \%$ of heat generation worldwide.
Among different countries throughout the world, Europe plays a pivotal role in biogas electricity generation. In 2017, Europe contributed to over $70 \%$ of the world biogas generation representing $64 \mathrm{TWh}$, followed by North America accounting for 15 TWh (in which the US participation was over $85 \%$ in entire North America). Asia produced 4 TWh followed by Eurasia with 1.7 TWh, South America with $953 \mathrm{GWh}$, and Africa biogas production accounted for 89 GWh (Scarlat et al. 2018; Agency 2019).

In terms of thermal energy production, biogas is turning to be a more significant source of heat, in which around $4 \%$ of the worldwide bioheat in 2015 was generated by biogas. In the EU, biogas produced $127 \mathrm{TJ}$ of heat, which corresponds to almost $50 \%$ of entire biogas use in the EU (Scarlat et al. 2018). In Demark, the electrical power cost produced by biogas is $0.056 \mathrm{EUR} / \mathrm{kWh}$ in a CHP unit or injected into the grid (Seadi and J. 2019).

Biogas utilization differs significantly in various countries around the world. This varies from several small-scaled biogas plants providing heat in China and India to largescale plants generating electricity as well as upgrading into biomethane as fuel, mostly in Sweden (McCabe et al. 2018).

Nanyang in China is one of the top biogas cities in the globe due to its location in the center of a rank soil zone. Since corn is abundant, other types of cereals can be employed for producing biogas (Dieter Deublein 2008; Lei Zheng 2020).

In China, biogas plants are classified as medium scale with the volume of digester equaled to 300 cubic meters and large scale with a capacity of 500 cubic meters, with daily biogas production in the range of 150 to 500 cubic meters per day (Song and C., Yang, G., Feng, Y., Ren, G., Han, X. 2014). The governmental support for domestic digester has been stopped since 2015. More backing would make largescale biogas plants and bionatural gas schemes (Ndrc 2015). Chinese biogas industry reported that 41.93 million biogas digesters were built (containing centralized biogas source for houses), for almost 200 million recipients, in which 14.5 billion $\mathrm{m}^{3}$ biogas is produced per year (China Statistics Press 2018).

In India, around 2.5 Mio biogas plants are operating, with a medium digester volume of $3-10 \mathrm{~m}^{3}$. Based on the circumstances, the plants produce $3-10 \mathrm{~m}^{3}$ biogas daily, adequate to deliver a regular farmer family with energy for food preparation, heating, and lighting. Also, more than 1.2 million households employ small-scaled AD and 100,000 family-sized AD units have been installed between 2016 and 2017. Over 35,000 biogas plants have been constructed with governmental investments (MNER 2016).

Japan is a pioneer in the use of biogas, with increasingly using $\mathrm{AD}$ to produce biogas and manage municipal waste in the last decade. The development is such that only Japan uses thermophilic AD (Abbasi et al. 2012). 
Up to 2008, over 70 plants have been constructed in Russia, over 30 in Kazakhstan, and a single plant in Ukraine. In Ukraine, bioreactors with $162,000 \mathrm{~m}^{3}$ volume have been previously installed in sewage treatment units (M. R. Atelge DK, Gopalakrishnan Kumar, Cigdem Eskicioglu, Dinh Duc Nguyen, Soon Woong Chang, A. E. Atabani, Alaa H. AlMuhtaseb, S. Unalan. 2018).

It should be noted that some nations employed biogas as a practical tool for waste management, mostly to decrease the detrimental effects of municipal waste or wastewater. Likewise, a broad range of various technologies are employed from simple digesters to expanded granular sludge blanket (EGSB) digesters (McCabe et al. 2018).

\section{Biogas technology and industry}

The biogas industry varies significantly in the various parts of the world. Different countries have been advanced in several types of biogas systems mainly premised on different environment as well as energy demand and supply chain. The UK, Australia, and South Korea employed landfill sites to achieve a considerable portion of their produced biogas, while in Switzerland and Sweden, using decomposition of sewage to generate biogas is prevailing. Denmark utilizes mainly manure due to its abundance and availability. In Germany, UK and Sweden most of the biogas generation arises from food waste (McCabe et al. 2018; Union 2015; Association WB.Global Potential of Biogas 2019).

In farm-based biogas production, China and Germany are recognized as world leaders since about 24,000 smallscale plants exist in China and nearly 8000 agriculture plants in Germany. Similarly, France, Holland, Austria, and Italy employed considerable farm-based biogas plants (Union 2015). Moreover, the scale of plants ranges from small household units to larger plants using feedstocks such as household waste, industrial waste, and manure to generate both heat and electricity (Union 2015). Studies revealed that in Asia and Africa, most of the installed biogas plants were family-sized (Kemausuor et al. 2018). China and India have dominated the microscale biogas industry in the world. At this time, Thailand takes benefits from more than 1700 biogas plants and more than 150 plants of industrial waste. The Thai government has attempted to expand industrial wastewater technology that has the potential of $7800 \mathrm{TJ} / \mathrm{y}$ biogas production (Tonrangklang et al. 2017). The ministry of energy of Nepal (Government of Nepal Ministry of Energy WRaI.Biogas.2020 2020) has reported that most of the villages about 2800 , out of the total 3915 in all 75 districts of Nepal, have small-scale or household biogas production systems. Primarily two categories of plants have been constructed in Nepal. These are the floating-drum plant based on the Indian style and fixed-dome plants with a flat floor, cylindrical digester, and a dome prepared by concrete.
Among 50 million microscale digesters operating in various parts of the world, 42 million are installed in China and another 4.9 million in India. The statistics from the World Biogas Association (WBA) have shown that there are only 700,000 biogas plants installed in Asia, Africa, and South America (Association WB.Global Potential of Biogas.2019. 2019).

In terms of large-scale plants, about 7000 large-scale biogas systems are operating in China. Europe, in 2017, had a share of 17,783 plants, while Germany was dominating the European biogas industry with 10,971 plants followed by Italy with 1665 plants, France with 742, Switzerland, and the UK with 632 and 613 plants, respectively (Association 2018). The World Biogas Association data mentioned about 2200 anaerobic digesters large-scale plants in the USA, able to generate $977 \mathrm{MW}$ (Association WB. International Market Report 2018).

Another application of biogas relies on upgrading to biomethane. Although being comparatively a novel technique, it achieves widespread utilization worldwide. Some biogas upgrade plants are employed to produce vehicle fuel, while others deliver it into the local or national grids Association WB.Global Potential of Biogas (2019).

Africa is a region with abundant and diverse resources for biogas production, though it has accomplished small progress in the sector. Although the continent has made considerable achievements in small-scale biogas plants, profitable biodigesters still require further development (Kemausuor et al. 2018). In Africa, harvest and livestock farmers, small to medium and large food treating businesses, wastewater, sanitation, and municipalities running institutes, as well as municipal waste management organizations, are considered as potential candidate employers of large-scale biogas technology. Moreover, schools, institutions of higher education, hospitals, and commercial buildings have the potential to benefit from biogas technologies and facilities (Parawira 2009). Excluding South Africa, insufficient scientific literature has reported technology development of the commercial biogas system in Africa. In the Southern parts of Africa, developed technologies are the lagoon, plug low, and upflow sludge blanket (UASB) (Mutungwazi et al. 2018).

\section{Biogas production and utilization}

In this section, biogas production from wastewater treatment plants (WWTP), biowaste digestion, agricultural products (largely manure and energy crops), waste stream from different industries, and landfill gas are considered. In Europe, Germany has dominated the industry by far in which its annual production is accounted for $120 \mathrm{TWh}$ followed by the UK with 25 TWh and 9 TWh in France. Denmark and the Netherland's production capacity is around $4 \mathrm{TWh}$ and 
the remaining countries share is less than $3 \mathrm{TWh}$ (Bioenergy 2019a).

In Germany, the total gross electricity and heat production from biogas is about $33 \mathrm{TWh} /$ year and $18.8 \mathrm{TWh} /$ year, respectively. Based on statistics revealed by the Federal Ministry for Economic Affairs and Energy of Germany, a considerable amount of the biogas was utilized for electricity production (58\%) and heat production (33\%), and approximately only $1 \%$ was used as a vehicle fuel (Bioenergy 2019a).

In 2018, about $32 \%$ of entire renewable heat used in the UK was produced by anaerobic digestion technology, of which $9 \mathrm{TWh} /$ year was produced by biomethane, $2 \mathrm{TWh} /$ year by biogas and CHP accounted for $918 \mathrm{GWh} /$ year, while $2681 \mathrm{GWh}$ of electricity was generated by the sector (Association ADaB. ADBA annual report 2019.2018).

In France, total electricity production from biogas was about $1.8 \mathrm{TWh} /$ year at the end of 2017, simultaneously total heat generated accounted for $1.7 \mathrm{TWh} / \mathrm{year}$, which demonstrates nearly equal portion for both heat and electricity. Regarding heat production, the agriculture sector accounts for an indispensable portion, while in electricity production, the landfill has a pivotal role with $953 \mathrm{GWh} /$ year followed by agriculture with $765 \mathrm{GWh} /$ year (Bioenergy 2019a).

In Denmark, the biogas sector provides 5\% of the entire energy consumption of which biogas plants contribution is $60 \%$ and the rest relies on wastewater treatment plants and landfill sites. The Danish Energy Agency states that due to several support schemes such as upgrading biogas to Natural gas, biogas employment for process purposes in the industrial sectors, etc. results in promoting biogas utilization through the country (Agency and Biogas in Denmark 2019). Total Danish biogas production at the end of 2018 was reported to be about $1763 \mathrm{GWh} /$ year in which the agriculture sector (both centralized and farm plant types) showed the largest contribution with $1367 \mathrm{GWh} /$ year. 66\% of produced biogas energy (which corresponds to $1150 \mathrm{GWh}$ ) is used to provide electricity, followed by upgrading plants with $17 \%$ portion and heat generation with $16 \%$ Bioenergy IEAI. Denmark Country Report -2019 (2019). In the Netherlands, in 2017, two co-digestion and municipal waste plants had the largest share in production, and the final use of biogas (3034 TJ heat was produced solely with municipal waste, while co-digestion had a pivotal role in electricity production representing $1825 \mathrm{TJ}$ ) Bioenergy IEAI.The Netherlands Country Report -2019 (2019).

In Sweden, $48 \%$ of biogas production corresponds to codigestion plants followed by WWTPs (37\%), the remaining being produced by the other plant types such as landfills, industrial facilities, and farm-based. In terms of utilization, the upgrading or transport sector represented a considerable portion $(65 \%)$ followed by heat (19\%), while electricity production share was almost 3\% (Bioenergy 2019b).
In Asia, China plays a significant role with $98.4 \%$ of biogas production between non-OECD countries. Primary infrastructures such as advanced industry and socioeconomic conditions have a profound impact on biogas generation and utilization growth. Small-scale and household biogas systems have been widely developed by countries like India and Bangladesh. Various researches prove that there are plenty of resources for producing biogas in developing countries when barriers such as socioeconomic, climate conditions, and appropriate technology have been addressed accurately. Several biogas plants in the range of medium to large scale have been launched in China and India (Mittal et al. 2019; Jiang et al. 2011; Gu et al. 2016).

In the USA, over 2200 biogas plants are operated, among which $250 \mathrm{AD}$ on farms, 1269 wastewater recovery plants employing an $\mathrm{AD}$, and 66 independent plants that use food waste as feed and 652 landfill gas projects. The America Biogas Council has revealed that there is still an enormous potential for developing the biogas industry in the USA where it is possible to achieve 103 trillion $\mathrm{kWh}$ /year (Council 2019a). California ranks first in biogas production potential among all the 50 states in the USA (Council 2019b), followed by Texas (Council 2019c).

The power generation from biogas is estimated to be 9731 million $\mathrm{kWh}$ and 6574 million kWh electricity for California and Texas states, respectively. In California, the manure system has the highest potential with about 900 biogas plants, while currently 38 manure plants are operated with 156 wastewater facilities in Texas. (Council 2019b,c).

In Canada, bioenergy currently provides approximately $26.7 \%$ of Canadian entire renewable energy market, the highest share is from burning solid biomass $(23.1 \%)$, followed by the liquid biofuels (2.4\%), and biogas (1.2\%) (Canada 2019). In Canada, total installed plants for biogas production are estimated to be around 150. Most production takes place in landfills with 45 plants (share of 30\%), followed by the agriculture sector with 37 plants (share of $24.7 \%$ ) and WWTPs with 31 plants (20.7\% production portion) (Association WB.Canada Market Report.2019. 2019).

Based on the Canadian Biogas Association data, at the end of 2018, about 195 MW of electricity and 400,000 GJ of Renewable Natural Gas (RNG) were generated (Biogas and Potential.2019. 2019). Biogas is utilized for providing heat and electricity, delivering to a nearby user using a pipeline, converting into electricity and connecting to the grid, or refining to RNG based on circumstances such as the landfill site location, and the energy demand of plants. In this regard, approximately $50 \%$ of the produced biogas is converted into power, with the rest going to combined heat and power (CHP) application (about 25\%), heat (only 10\%) and RNG (about 4\%), and electricity and RNG (about 1\%) (Association WB.Canada Market Report.2019. 2019). 
In Australia, at the end of 2017, generated electricity from biogas industry was approximately $1200 \mathrm{GWh}$, which is equivalent to almost $0.5 \%$ of the entire electricity generation of the country, while biogas potential electricity generation was estimated as $103 \mathrm{TWh}$, equal to almost $9 \%$ of Australia's entire energy consumption (Australia and Biogas opportunities for Australia. 2019).

The main use of biogas in Australia is for electricity with the greatest share for landfills (53.7\%), followed by biowaste and WWTPs (40\% and $33.3 \%$, respectively). Heat is used in the industrial sector with a share of $30 \%$ and afterward the WWTPs with a share of $26.2 \%$. In CHP applications, agriculture plants have the largest portion (50\%), followed by the biowaste and the WWTPs (equal share of about $20 \%$ each). Between $40-50 \%$ of the excess biogas is flared at agriculture, industries, and landfills. Twenty percent of WWTPs and biowaste are no biogas upgrading plants in Australian's biogas industry (Bioenergy IEAI.Australia Country Report.2019. 2019).

In Africa, South Africa has the largest share of installed biogas plants with about 700 plants, while only 300 plants might have been in operation as of 2007, while it can generate $148 \mathrm{GWh}$ electricity from estimated biogas potential by appropriate investment and implementation schemes (Kemausuor et al. 2018).

Various industrial trends in the biogas production have been introduced to improve quantitative and qualitative properties of the biogas. Yet, the accomplishments of $\mathrm{AD}$ intended for advanced investments will increase from the low charge of feedstock accessibility and the broad range of practical set ups of the biogas (i.e., heating, electricity power, and fuel form). The remained parts of slurry from biogas production procedure have the potentials to be improved to be used as fertilizer to enhance the sustainability. Produced biogas could be employed to generate power for integrated or isolated systems in the rural and urban regions and are deemed to be economical favorable. The employed processes of $\mathrm{AD}$, modern trends accompanied by included advantages and disadvantages are also demonstrated more details and progress on the way to producing biogas in a sustainable approach. Obtained results from previous researches indicated that the present amount of biogas production confirms that regarded approaches would have main influence on the energy utilization in upcoming times. The impression contains diminished release of pollutants to the atmosphere guarantees that the global warming prevention. Nevertheless, the current trend of the biogas production varies in diverse countries, either in production or the sources (landfill, AD, sewage sludge, or thermochemical methods). The involvement of biogas to the domestic natural gas utilization varies differently, around $4 \%$ on standard values; however, it raised $12 \%$ in Germany. The major nations in the biogas production in the European Union are France, Italy, Germany, Czech, and UK. Germany stands as the European frontrunner with a biogas production of $329 \mathrm{PJ}$ and a contribution of $50 \%$ of total in the EU. It's reasonable to surmise that, based on the provided data from various researches, it has been declared that given the growing need and available technology, European Union countries, and especially Germany and Sweden, will be pioneers in the development, operation, and production of biogas in the world. Table 1 indicates the biogas plants, upgrading units, and their upgrading capacities in certain EU countries (Lampinen 2015; Backman and Rogulska 2016; Esmaeilion et al. 2021).

\section{Recent progress in biogas production}

Producing biogas is a key option in the energy sector of various countries. There is a wide variety of raw materials for utilization in biogas plants. In this case, obtaining a stable state in plants is a crucial concern that influences the prices and additives. Another important issue in the biogas plants is that their products should be attractive in terms of value and efficiency (Chen et al. 2012). Recent progress in the field of biogas production can be divided into three categories: feedstock and additives, pretreatments, and processes.

\section{Feedstock and additives}

The organic matters are the main feedstocks in the biogas plant, which can fall into different categories. Evaluating the potential of biogas production based on organic matters from rural regions has been investigated. The highly fermentative wastes can decrease the quantity of feedstock in biogas plants (Pawlita-Posmyk and Wzorek 2018).

Microalgae with satisfactory features is a potential option for feedstock in biogas systems. In comparison with other biomass resources, microalgae has better efficiency, more convenient production, and higher content of lipid and polysaccharide that make it a flexible choice in biogas plants ( $\mathrm{Wu}$ et al. 2019). Kaparaju et al. (Kaparaju et al. 2009) explored

Table 1 Biogas plant in EU selected countries and their specifications

\begin{tabular}{llll}
\hline Country & Biogas plants & $\begin{array}{l}\text { Biogas upgrad- } \\
\text { ing plants }\end{array}$ & $\begin{array}{l}\text { Biogas } \\
\text { capacity } \\
(\mathrm{Nm} 3 / \mathrm{h})\end{array}$ \\
\hline Germany & 94 & 120 & 204,082 \\
Austria & 9066 & 10 & 5160 \\
Italy & 1264 & 1 & 540 \\
Sweden & 187 & 53 & 38,858 \\
Netherlands & 211 & 16 & 16,720 \\
UK & N/A & N/A & 18,957 \\
Switzerland & N/A & N/A & 6310 \\
\hline
\end{tabular}


the production of biogas from sugars released from wheat straw with the aid of hydrothermal pretreatment based on the biorefinery procedure. In this case, the pretreatment process increased the gas yield by $10 \%$.

For achieving sustainable progress, the global trend of energy production is moving to the waste-to-energy (WTE) method which has multilateral benefits. Currently, biomass resources are being employed to generate energy. All around the world, biomass satisfies around 50 exajoule of the entire energy demand annually (Steubing et al. 2010; Ferreira et al. 2017; Ahmadi et al. 2020).

A broad spectrum of waste types can be consumed as a feedstock in biogas units by anaerobic digestion (AD) technology. Huge amounts of lignocellulosic waste could be collected from agricultural and municipal resources. The most common types of waste and residuals that can be used in the biogas sector are animal manures and dungs, muck and slurry, domestic/municipal wastewater (sewage), mud (sludge), urban garbage or municipal solid waste (MSW), and food substances loss. Table 2 indicates the power generation and associated yields of biogas production by accessible resources (Waste-to-energy 2015; Stucki et al. 2011).

To enhance the yield of biogas production, utilization of additives is an acceptable method. Specifications of these components can be varied based on their biological or chemical properties under various conditions. With the aid of these materials, desirable conditions for bacteria could be provided. However, biocenosis features are vital for achieving the ideal concentration (Demirel and Scherer 2011).

Using salts with $\mathrm{Mg}$ and $\mathrm{Ca}$ improves methane production efficiency with low slurry foaming (Sreekrishnan et al. 2004). For stabilizing pH fluctuations and reducing the contents of $\mathrm{NH}_{3}$ and $\mathrm{H}_{2} \mathrm{~S}$, several types of additives have been studied (Kuttner et al. 2015). Furthermore, using zeolite compounds has the potential to intensify the quantity of biogas production by $15 \%$, also the addition of $\mathrm{CaCO}_{3}$ can improve this yield by $8 \%$. Adding biological additives increased the production rate of biomethane and biogas by optimizing AD (Vervaeren et al. 2010). Using biological additives is a common way of increasing biogas production yield. Yi Zheng et al. (Zheng et al. 2014) stated that by adding enzymes to lignocellulosic biomass, biogas production was enhanced by $34 \%$. Vervaeren et al. (Vervaeren et al.
2010) reported that by adding homo and hetero-fermentative bacteria to maize components, production yield increased by $22.5 \%$. With the addition of fungi compounds (e.g., ceriporiopsis subvermispora ATCC 96,608) to the yard trimmings, methane production increased by $154 \%$ (Zhao 2013). The alternative options for biological additives are chemical compounds. Using a wide variety of chemical additives like $\mathrm{NaOH}, \mathrm{Ca}(\mathrm{OH})_{2}, \mathrm{NH}_{4} \mathrm{OH}, \mathrm{H}_{3} \mathrm{PO}_{4}$, etc., can improve the associated biogas production yield. Chandra et al. reported the effects of using $\mathrm{NaOH}$ as an additive to the wheat straw. Obtained results presented that yield of methane could be improved by up to $112 \%$ (Chandra et al. 2012). Badshah et al. investigated the diluted $\mathrm{H}_{2} \mathrm{SO}_{4}$ properties, added to the sugarcane bagasse, which could increase the production rate by up to $166 \%$ in comparison with pre-additive treatments (Badshah et al. 2012).

The impact of activator addition on the biogas quality slurry is investigated in Indonesia (Ginting 2020), the study started by adding new bioactivator prepared from agricultural wastes such as bananas, papayas, and pineapples waste with an additional of chicken intestines where the bacteria in the chicken intestine are effective at work. The addition of the activator resulted optimally in the work where stable gas production was achieved. The slurry at the end of the production process was a liquid fertilizer ready to use. The study showed the best concentration of the activator in the production process of both the slurry and the biogas.

\section{Pretreatment}

Predominantly, there are two wide-ranging classifications for biogas production upgradation, ex situ, and in situ techniques, while most of the methods focus on ex situ approaches. Some of the conventional ex situ treatments are adsorption, catalytic processes (e.g., biological or chemical), membrane gas permeation, desulfurization, scrubbing, and absorption. Sarker et al. (2018) overviewed the in situ biogas production upgrades.

With the help of the in situ method, the associated cost concerning cleaning techniques could be reduced and the quality of produced biogas improved in the same vein. Nevertheless, the in situ method is limited to the empirical state and prototype models. Figure 2 summarizes various types of

Table 2 Comparison between different resources in terms of biogas yield and electricity generation

\begin{tabular}{lllllllll}
\hline Resources types & Fat & Food waste & MSW & Cattle dung & Fruit wastes & Maize silage & $\begin{array}{c}\text { Sewage sludge } \\
\text { Chicken } \\
\text { litter/ } \\
\text { dung }\end{array}$ \\
\hline Biogas yield (m³/ton) & $826-1200$ & 110 & 101.5 & $55-68$ & 74 & $200-220$ & 47 & 126 \\
Electricity produced (kWh/ton) & 1687.4 & 224.6 & 207.2 & 122.5 & 151.6 & 409.6 & 96 & 257.3 \\
\hline
\end{tabular}

Considered efficiency for electricity production is $35 \%$ in CHP 
Fig. 2 Biogas improvement by ex situ and in situ techniques (Sarker et al. 2018; Bassani et al. 2016; Rachbauer et al. 2016; Lemmer et al. 2015)

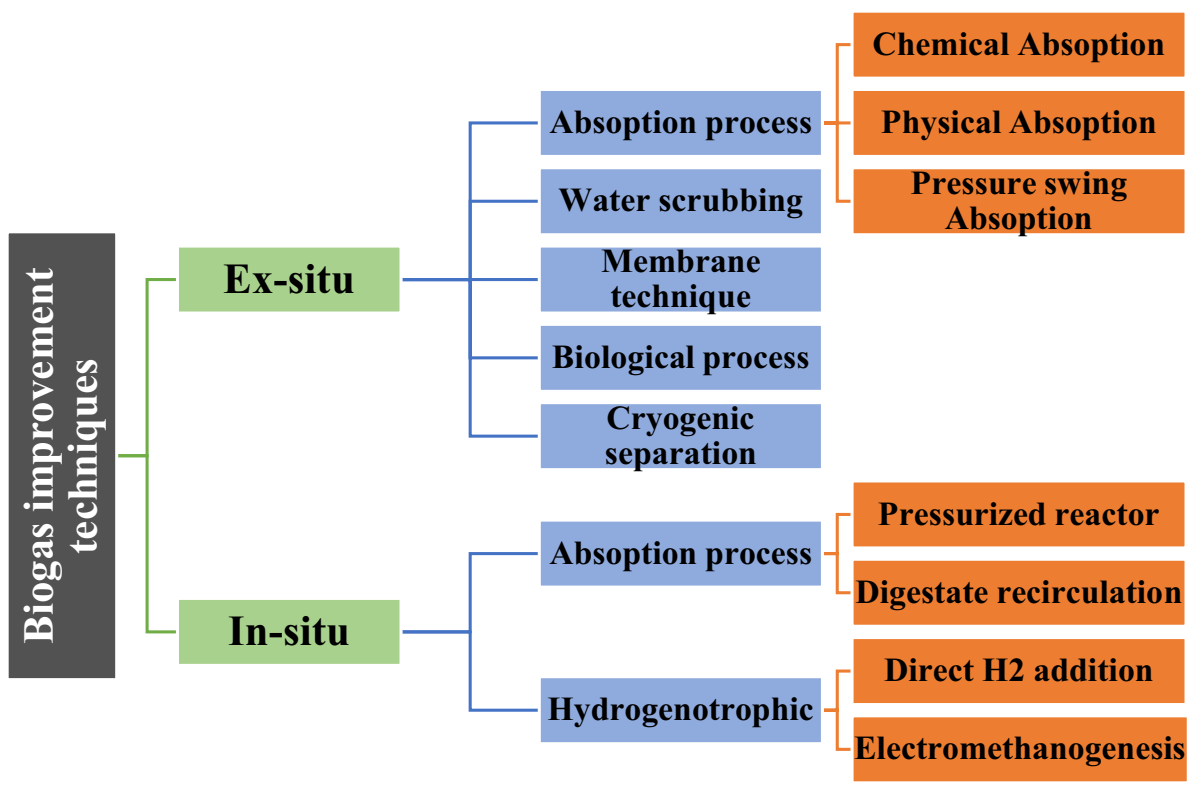

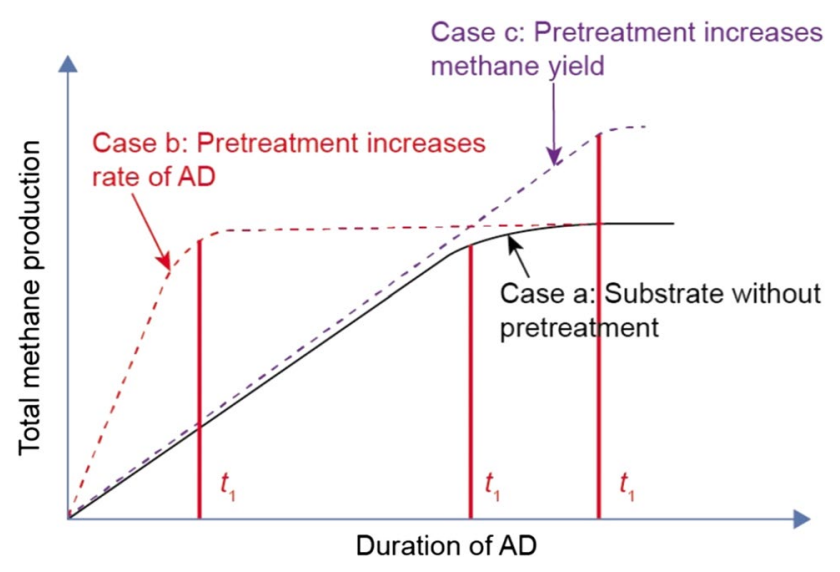

Fig. 3 Pretreatment effects on the value of anaerobic digestion (b) and yield of $\mathrm{CH}_{4}$ (c) (Achinas et al. 2017)

biogas upgrading methods (Sarker et al. 2018; Bassani et al. 2016; Rachbauer et al. 2016; Lemmer et al. 2015).

The pretreatment productivity influences the associated bioprocess efficiency of lignocellulose. Pretreatment techniques are intended to make $\mathrm{AD}$ faster, enhancing the yield of the biogas, and producing a broad range of usable substrates.

Figure 3 indicates the mentioned effects of pretreatment processes. By considering efficiency, economy, and application as objective functions, optimization of pretreatment processes is a necessitated aim. Pretreatment should be operative in eradicating the structural obstacles of associated polymers with lignocellulose (it should be noted that the cellulose and hemicellulose constituents are in this classification), through exposing these substances to microbial decay efforts, which increases the biomass degradation and consequently enhances the biogas yield (Spyridon et al. 2016).

There are crucial requirements in common designs of biogas plants for increasing the rate of gas production. Recently, innovative designs of biogas plants have been introduced (e.g., Konark, Deenbandhu, and Utkal Models) (Sreekrishnan et al. 2004; Kalia and Singh 2004; Abouelenien et al. 2010; Prasad et al. 2017) in which the design parameters changed to increase productivity and effectiveness in cost factors. In these concepts, by implementing optimum measurements in regarded shapes (similar to the spiral shape), the index of gas storage volume was enhanced by $33-50 \%$, while the related costs were reduced by $10-15 \%$.

The hydrolysis of a high proportion of non-biodegradable compositions from MSW (which is intractable by AD) can be performed by microwaving or autoclaving (Pecorini et al. 2016). In another study, by applying pressure to biowaste in the pretreatment procedure, biogas yields were improved significantly (Micolucci et al. 2016). The most desirable condition in the pretreatment of biomass is to provide an ideal environment for breaking down the feedstock substances to the sugars that are fermentable, by increasing the accessibility for microorganisms. This process leads to eradicating the lignin endurance and declining the cellulose's crystalline formation (Micolucci et al. 2016). Table 3 presents the merits and demerits of various pretreatment technologies.

By implementing fast pyrolysis pretreatment, biogas production has been increased (Wang et al. 2016a). This innovative approach in thermochemical pretreatment with the aid of a lower temperature fast pyrolysis (LTFP) to enhance the performance of the $\mathrm{AD}$ process has been introduced, in which corn stover was used as a primary substance. 
Table 3 Merits and demerits of pretreatment techniques

\begin{tabular}{|c|c|c|c|c|}
\hline No & Processes & Merits & Demerits & References \\
\hline 1 & $\begin{array}{l}\text { Steam pretreatment/steam explo- } \\
\text { sion }\end{array}$ & $\begin{array}{l}\text { Increases the reaction of cel- } \\
\text { lulose fiber }\end{array}$ & $\begin{array}{l}\text { High risk of forming inhibiting } \\
\text { mixtures. A smaller amount of } \\
\text { digestible biomass Precipitation } \\
\text { reaction }\end{array}$ & $\begin{array}{l}\text { Taherzadeh and Karimi (2008), } \\
\text { Chandra et al. (2007) and } \\
\text { Montgomery and Bochmann } \\
\text { (2014) }\end{array}$ \\
\hline 2 & Microwave & More biogas production (4-7\%) & - & Shahriari et al. (2012) \\
\hline 3 & Liquid hot water & $\begin{array}{l}\text { High risk of forming inhibiting } \\
\text { compositions } \\
\text { Increases the accessibility of the } \\
\text { enzymes }\end{array}$ & $\begin{array}{l}\text { High thermal energy consump- } \\
\text { tion } \\
\text { Operates at a certain temperature }\end{array}$ & Laser et al. (2002) \\
\hline 4 & Extrusion & - & $\begin{array}{l}\text { High cost } \\
\text { High energy consumption }\end{array}$ & $\begin{array}{l}\text { Chandra et al. (2007) and Olofs- } \\
\text { son et al. (2008) }\end{array}$ \\
\hline 5 & Strong acid pretreatment & $\begin{array}{l}\text { Make hemicellulose soluble } \\
\text { Adaption feature of Methanogens }\end{array}$ & $\begin{array}{l}\text { High risk of forming inhibiting } \\
\text { mixtures and corrosion } \\
\text { High cost }\end{array}$ & Sumphanwanich et al. (2008) \\
\hline 6 & Alkaline pretreatment & $\begin{array}{l}\text { Make hemicellulose and lignin } \\
\text { soluble } \\
\text { Increasing the production of } \\
\text { methane }\end{array}$ & $\begin{array}{l}\text { High risk of forming inhibiting } \\
\text { mixtures } \\
\text { High risk of forming a concen- } \\
\text { trated alkali }\end{array}$ & Torres and Lloréns (2008) \\
\hline 7 & Milling & $\begin{array}{l}\text { Increasing the production of } \\
\text { methane (5-25\%) Lack of pro- } \\
\text { duction inhibiting mixtures }\end{array}$ & $\begin{array}{l}\text { High cost } \\
\text { High energy consumption }\end{array}$ & $\begin{array}{l}\text { Zheng et al. (2014), Ariunbaatar } \\
\text { et al. (2014) and Hendriks and } \\
\text { Zeeman (2009) }\end{array}$ \\
\hline
\end{tabular}

During the pretreatment procedure, a fluidized bed pyrolysis reactor applied high-temperature gas flow at $200{ }^{\circ} \mathrm{C}$. To improve the efficiency, different strategies in the pretreatment section were performed (e.g., characteristics analysis, assessing crystal concentration of the corn stover components). Comparing the results obtained between preand post-treatment, the production efficiency of methane increased by about $18 \%$. In thermochemical pretreatment, chemical bonds in substances would be broken by implementing the thermo-physical process. Biogas production and hydrolysis of celluloses are affected by the degradation of hemicellulose and lignin (Cara et al. 2006). Thus steam explosion falls into this category (Bauer et al. 2014). In this method, biomass is subjected to high-temperature steam at $240{ }^{\circ} \mathrm{C}$, so that after a long time, morphological and chemical transformations in biomass can occur (Biswas et al. 2011). Another pretreatment method to upgrade the biomass is the Torrefaction process which is applied to produce a higher amount of hydrophobic fuel with a fixed range of carbon content. The operational temperature for this process is from 200 to $300{ }^{\circ} \mathrm{C}$ in a stable environment (Mafu et al. 2016; Sarkar et al. 2014). Fast pyrolysis is an additional pretreatment that was highly used in the field of biofuel production. In this case, by reducing the temperature (around $200{ }^{\circ} \mathrm{C}$ ) lignin and hemicellulose could be wrecked. Nonetheless, there is no study demonstrating an increase in biogas production (Bridgwater 2012; Y-m et al. 2009). Rodriguez et al. (Rodriguez et al. 2017) investigated different pretreatments for grass in biogas production sectors. The obtained results revealed that all pretreatments could increase biogas production by around 50\% even though all of them suffer from high energy consumption.

The ultrasonic pretreatment process is an innovative and practical technique in the pretreatment section. This process increases the efficiency of sludge dewatering, stability of the digestion, solids solubility, and rate of biogas production. The outcome of this method is a digestate containing a low share of residual organic materials. The ultrasonication modifies the biological, chemical, and physical specifications of the sludge. Some of these variations are pathogen reduction, settling velocity improvement, and protein concentrations increase (Cella et al. 2016; Liu et al. 2015; Feng et al. 2009).

By applying this pretreatment, the rate of $\mathrm{CH}_{4}$ production increased by $34 \%$ (up to $80 \%$ of energy consumption in the pretreatment unit is reachable by produced methane) (Mirmasoumi et al. 2018). The Lysis centrifuge consists of a method focused on centrifuge which initiates partial destruction in sludge cells. This strategy can improve biogas production by $15-26 \%$ with thickened sludge resources. This practice is suitable in pretreatment processes (for dewatering) and does not impose any extra load on the system for extra operations (Dohányos et al. 1997).

Biological pretreatment is an alternative for thermal and chemical pretreatment that is composed of different stages like enzymatic hydrolysis, using fungi additives and thermal phased AD (TPAD). Among named processes, TPAD has attracted attention. The benefits of this biological pretreatment are lower energy consumption and higher biogas production in comparison with other methods (Zhen et al. 2017; Bolzonella et al. 2012). 
By comparing the results between thermal and autohydrolysis pretreatments, the production of biogas in the biological procedure is considerably lower than in the thermal pretreatment (26\% and $45 \%$, correspondingly). The dominant conditions of autohydrolysis pretreatment were reported to be at $55{ }^{\circ} \mathrm{C}$ for $12-24 \mathrm{~h}$ compared with $170{ }^{\circ} \mathrm{C}$ for half an hour for thermal pretreatment (Carvajal et al. 2013). In this field, the highest yield achieved in biogas production was investigated by Bolzonella et al. (Bolzonella et al. 2012) by applying the pretreatment at $70{ }^{\circ} \mathrm{C}$ for 2 days, with associated yield increasing by up to $145 \%$. It is noteworthy to mention that many studies have investigated the combined pretreatment for increasing the biogas production yield (Liu et al. 2018; Bao et al. 2015; Chan et al. 2016; AbelleiraPereira et al. 2015; Wang et al. 2014; Bentayeb et al. 2013) however, this is out of the scope of this study.

\section{Process}

The biogas production can be categorized into two main fermentation process which are dry and wet processes. For the digestion by wet process, the overall solids concentration in the fermenter is lower than $10 \%$. To treat solid substrates, using liquid manure for achieving pumpable slurry is necessary. On the other hand, in the dry digestion, the overall concentration of solids in the fermenter is ranging from 15 to $35 \%$. The stability in the wet digestion processes is higher than in dry methods. In the agricultural section, wet digestion practices are more widespread (Weiland 2010).

The biogas production procedure includes four important phases which are hydrolysis, acidogenesis, acetogenesis, and methanogenesis as can be seen in Fig. 4.

For developing methane fermentation, diverse associations of bacteria are needed, which are aceticlastic and hydrogenotrophic methanogens, syntrophic acetogens, fermentative bacteria, and homoacetogens. The balanced contribution between them increases the efficiency of biogas production and the AD process (Chen et al. 2016). There is a specific type of $\mathrm{AD}$ that involves anaerobic membrane bioreactors (AnMBRs), which increases the quantity of biogas production by membrane specifications. By considering the techno-economical parameters of AnMBRs, the efficiency of biogas production has the potential to be increased dramatically (Chen et al. 2016). Figure 5 shows the different types of AnMBR technologies.
Fig. 4 Diagram of the biogas production procedures by $\mathrm{AD}$ (Mao et al. 2015; Visvanathan and Abeynayaka 2012)

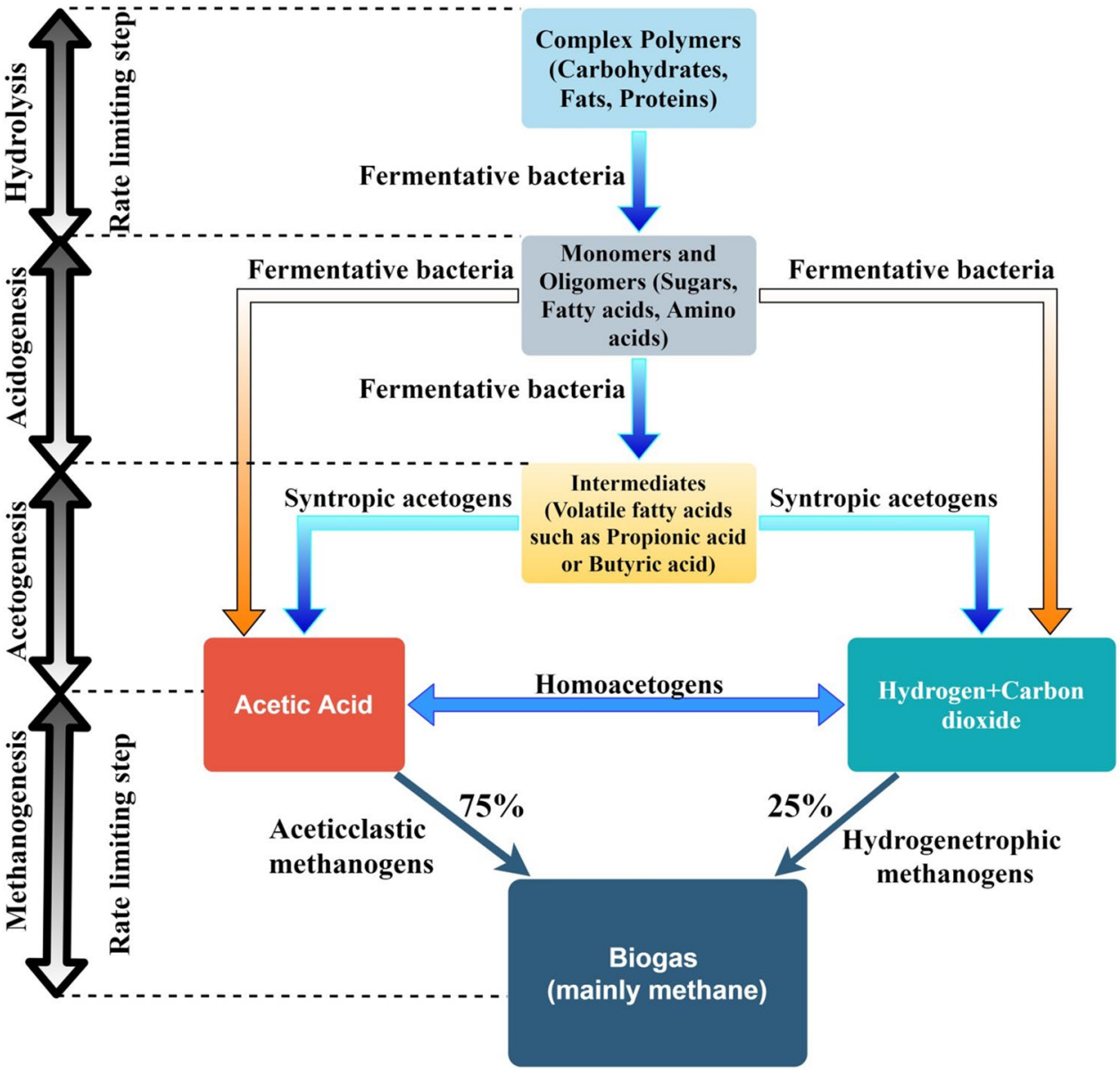




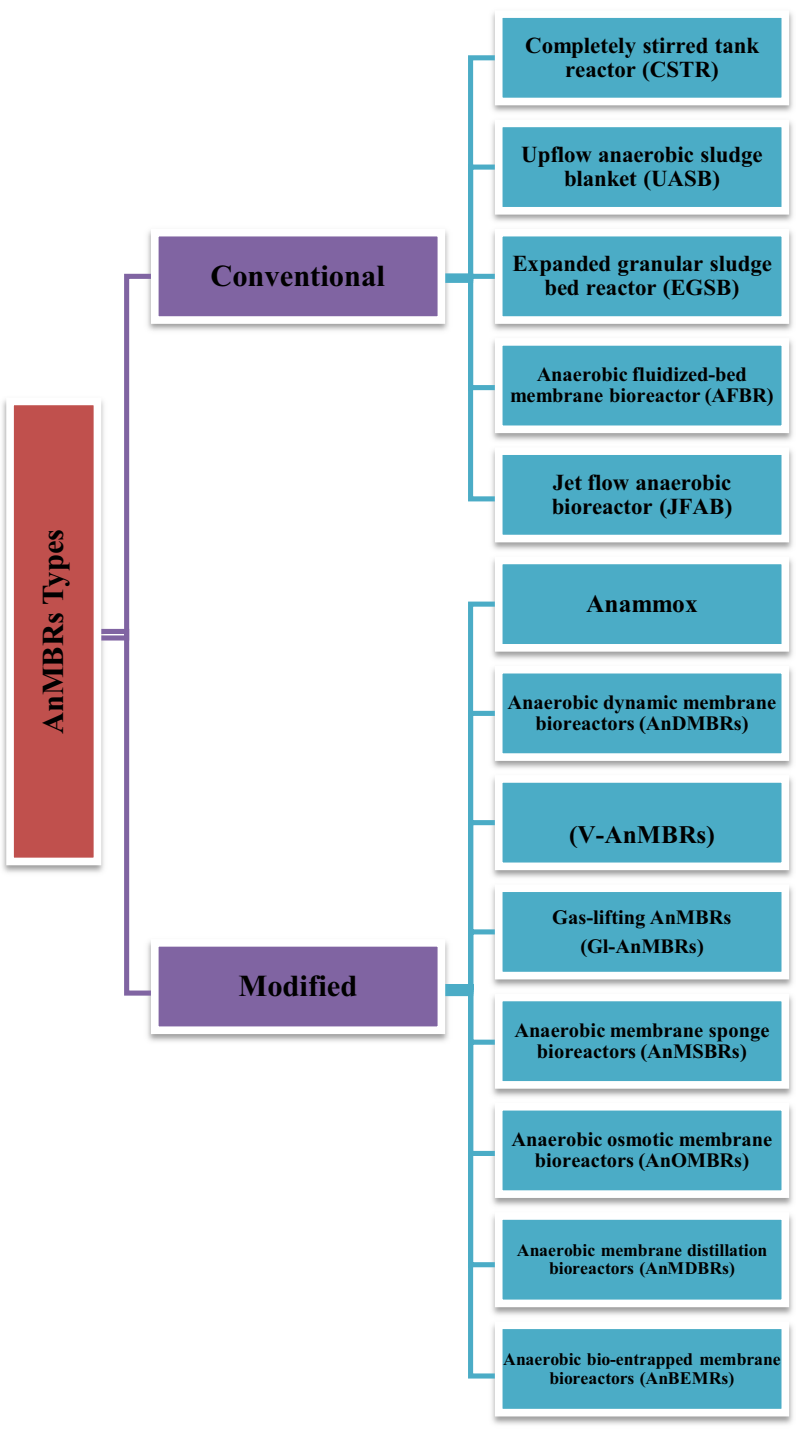

Fig. 5 The biogas production processes by different types of AnMBR technologies

The methanogenic organisms have a negative instinct for sluggish growing, and also the complexities of microbial in the systems have caused difficulty in the functioning of biogas fermenters. An innovative concept of integrating the anaerobic bioprocess with membrane breakdown practice through a membrane bioreactor (MBR) allowed augmenting the biomass concentration through a bioreactor. With an anaerobic membrane bioreactor (AnMBR), high hydraulic load, and adequate mixing brought sustainability for high cell concentrations (Wang et al. 2011).

The AnMBRs have a special feature for providing satisfactory retention of active microorganisms. This specification leads to optimal productivity and favorable resistance against toxic substances. Furthermore, high concentrations in the final product and easy separation of biomass and products (by micro-/ultra-filtration) have been added to its benefits (Ylitervo et al. 2013). Obtained results revealed that methane yield in biogas production was up to 0.361 $\mathrm{CH}_{4} / \mathrm{g}$ chemical oxygen demand (COD) and methane content reached $90 \%$ (Liao et al. 2010).

Wang et al. (Wang et al. 2011) discussed the developing approaches for the biogas sector in China and presented every aspect of this technology including the AnMBRs. Ylitervo et al. reviewed the MBR strategy for producing ethanol and biogas and explained the progress in MBRs (Ylitervo et al. 2013). Minardi et al. (Minardi et al. 2015) reported various applications of the membrane in biogas technologies and purification methods. Mao et al. (He et al. 2012) investigated the latest trends in biogas production by $\mathrm{AD}$ and AnMBRs. To improve the efficiency of AD, numerous investigations have been focused on various configurations (like single- or multiple-stage reactors).

The latest studies considered the breakdown of the $\mathrm{AD}$ method into two groups. For example, acetogenesis-methanation and hydrolysis-acidogenesis are accomplished in unconnected reactors, which can enhance the rate of the conversion process of organic matters to $\mathrm{CH}_{4}$, although the high prices associated with these types of systems are a critical issue (Yu et al. 2017).

More stability and improved efficiency are the outcomes of utilizing multiple-stage bioreactor systems. These types of systems allow for different conditions to be implemented. Obtained results from (Colussi et al. 2013) revealed that the two-step AD of corn requires a greater oxygen demand. Marín Pérez et al. (Pérez and Weber 2013) stated that the AD physical parting into two phases established the acceptance of various procedure settings for a particular bacteria type, which increased the degradation rate of organic materials. For preventing ammonia inhibition, the two-stage AD of MSW has been implemented (Yabu et al. 2011).

A study conducted in 2008 evaluated the one- and twostage $\mathrm{AD}$ in terms of performance. Results showed that the two-stage process had an advanced yield of $\mathrm{CH}_{4}$ production (Park et al. 2008). Figure 6 shows the schematic of multistage AD technology.

A two-stage AD system has a suitable potential to process a variety of residuals with high microbiological contents. Blonskaja et al. (Blonskaja et al. 2003) stated that by using a two-phase $\mathrm{AD}$ for distillery waste, a higher rate of methane would be produced. Kim et al. (Kim et al. 2011) implemented a four-phase scheme for activated slurry, which allowed extraordinary digestion productivity. The latest improvements in the utilization of molecular biology implements have developed the utility of included microorganisms and the knowledge of the AD practice. Bioindicators and innovative eco-physiological considerations are the ultimate enhancements of the chemical indexes for monitoring and controlling the stability of the AD process (Lebuhn et al. 
Fig. 6 Standard diagram of a multiple-stage scheme of AD technology

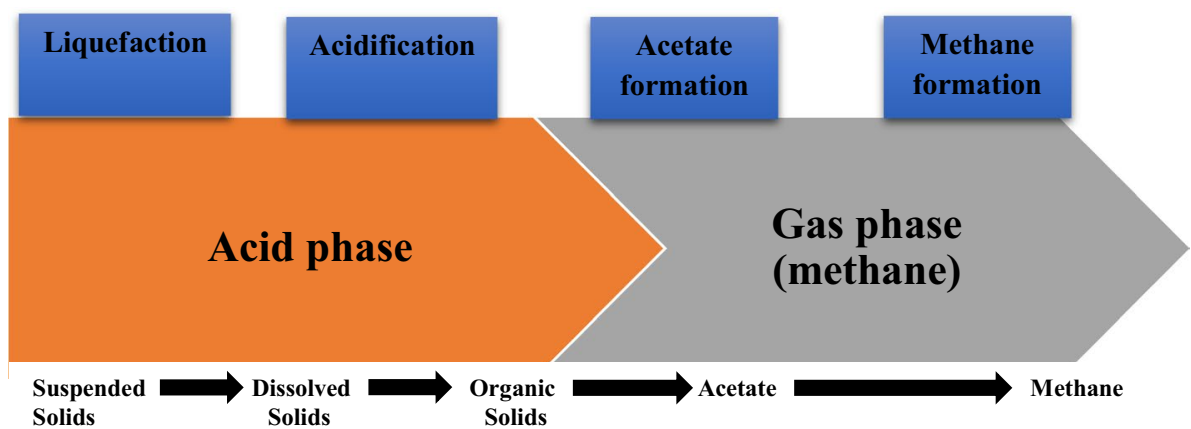

2014). AD process with renewable feedstock has been introduced as a forthcoming method for biogas production. The biogas chiefly consisted of $\mathrm{CH}_{4}(60 \%)$ and $\mathrm{CO}_{2}(35-40 \%)$. (Abdeshahian et al. 2016).

With the aid of the pyrolysis process, pyrolysis gas from biomass resources can be produced. Pyrolysis gas consists of carbon monoxide, hydrogen, carbon dioxide, and extra gases in minor quantities, e.g., methane and some specific components. The biomass resources are lignocellulosic biomass, MSW, lignite, and digestate. The most important advantage of pyrolysis is that the organic components (specifically the relatively dry and gradually biodegradable biomass that is not appropriate for the AD process) can be converted to pyrolysis gas (Luo et al. 2016). In the pyrolysis gas production, a methanation process is essential. Traditional catalytic methanation needs high pressure and temperature $\left(230-700^{\circ} \mathrm{C}\right)$ and a metal catalyst, which imposes high cost with low energy efficiency (Guiot et al. 2011). Li et al. (Li et al. 2017a) have investigated the new approach for employing pyrolysis products as a reservoir of carbon for biogas production. In this study, the effects of different parameters on biomethanation of pyrolysis gas have been assessed.

Different strategies, i.e., hydrothermal pretreatment (HTPT), ultrasonic method, alkaline method, and a combination of them, have been used for the dewatering of biomass materials. By considering every aspect of their functions, HTPT has provided the intended benefits (e.g., hot compressed water utilization and decomposing extracellular polymeric substances) (Park et al. 2017; Ruiz-Hernando et al. 2015).

A prototype for combining hydrothermal pretreatment with pyrolysis and AD process for cogeneration of biogas and biochar has been presented (Li et al. 2018). In the hydrothermal pretreatment (HTPT) stage, by heating sludge at $180{ }^{\circ} \mathrm{C}$ for half an hour, the water content fell significantly (from 85 to $33 \%$ ) and dewaterability improved. After that, filtration outputs were subjected to mesophilic AD without any interruption at an approximate temperature of $37^{\circ} \mathrm{C}$. An up-flow anaerobic sludge-bed reactor has been used for biogas production to be consumed in the hydrothermal pretreatment section. Concurrently, for producing heavy biochar, a rotary kiln has been utilized for filter cake pyrolysis at about $600{ }^{\circ} \mathrm{C}$. The considered configuration included a boiler, a pressure filter, a cooling chamber, and a hydrothermal reactor. The sludge was fed into the first reactor (A) and for diluting the sludge, some water was added (20\%). In the next reactor, the superheated steam raised the temperature of the sludge $\left(190{ }^{\circ} \mathrm{C}\right)$. By discharging the steam to the first reactor, the pressure in the second reactor decreased (less than $0.11 \mathrm{MPa}$ ) and drained steam used for preheating the input sludge (Li et al. 2017b).

Hübner et.al (Hübner and Mumme 2015) proposed a design for biogas production by using aqueous liquor from digestate pyrolysis. In the applied conditions, three main liquors were produced by the pyrolysis process (at 330, 430, and $530{ }^{\circ} \mathrm{C}$ ) under four chemical oxygen demand (COD) concentrations $\left(3,6,12\right.$, and 30 g. $\left.\mathrm{L}^{-1}\right)$. At 3 g.L $\mathrm{L}^{-1}, 6$ g.L $\mathrm{L}^{-1}$, and 12 g. $\mathrm{L}^{-1}$ a considerable increase in biogas has been observed. Besides, an important feature was that the biogas production in this process did not need any additives.

The studies based on the microbiology field are developing the concept of hydrolytic microbes and biogas production correlation. These types of investigations focused on the hydrolytic microorganisms' involvement in biogas units, metabolism types, and their functionality in regarded processes. Azman et al. (Azman et al. 2015) studied the participation of anaerobic hydrolytic microbes in biogas production from lignocellulosic (by considering microbiological features). Nina Kolesáarová et al. (Kolesárová et al. 2011) examined the possibilities for producing biogas with biodiesel by-product as a feedstock in various phases. Yang et al. (Yang et al. 2014) presented a membrane gas-permeation for biogas upgrading. In this study, the authors implemented polymer membranes to upgrade biogas production. Furthermore, Miltner et al. (Miltner et al. 2017) reviewed innovative technologies in purification and production of biogas. Kiros Hagos et al. (Hagos et al. 2017) presented an anaerobic co-digestion (AcoD) process for producing biogas from various diverse biodegradable organic sources. The digestate (fermentation residue) had a high content of moisture that should be dried for increasing the nutrient concentration and decreasing the transported mass. In this case, 
using a solar greenhouse dryer in tandem with heat recovery from combined heat and power and a microturbine provided a logical opportunity to eradicate the undesirable moisture content. The hybrid case had the potential to reduce moisture content by up to $80 \%$ (Maurer and Müller 2019). Owing to the faster reaction rates and higher productivity, the thermophilic digestion method is more satisfactory than mesophilic digestion. The mesophilic digestion method leads to a low methane yield and the related biodegradability is relatively poor. On the other hand, these systems represent enhanced stability and higher concentration in bacteria distribution. Unexpected thermal fluctuations affect methanogens performance; as a result, any extreme variation in temperature is undesirable. In this case, it is better to coat the facilities of biogas plants with insulators to control the digester temperature. By building sun-facing biogas units, the effect of cold winds would be eradicated. The integrated system consisted of a solar system and a biogas plant, which provided satisfactory results in gas yield values during cold seasons (Horváth et al. 2016).

Therefore, it is reasonable to surmise that biogas production has been influenced by different parameters and factors, including pretreatment processes, feedstock, and additives features, and process technologies. Provided data appear to confirm the following summary of key points.

- Production of biogas is an approach for biomass treatment and can help energy generation sustainably. Proper potentials for fossil fuel replacements increased the attention to biogas upgrading and advanced pretreatment methods. The biogas pretreatment procedure has two main steps: 1. biogas cleaning methods and 2. biogas upgrading method. With the help of these strategies, the lignin layer would be broken and the biomass turns to a suitable feedstock for the digestion process, while the porosity increases simultaneously. Hereon, the biogas yield would be improved (based on the feedstock types and associated technologies, obtained rates would be different).

- There are different techniques for biogas upgrading that each one has a specific contribution based on the applied commercial technologies. Waster scrubber, chemical scrubber, membrane pressure swing adsorption, and organic physical scrubber contributed the most accounting for $35 \%, 21 \%, 20 \%, 17 \%$, and $5 \%$, respectively.

- An extensive variety of compositions has been evaluated and observed for biogas production. Crop biomasses (wheat, barley, etc.), organic wastes (MSW, agro-industry wastewaters, animal manners, etc.), crop residues (wheat straw, barley, or rice straw, etc.), and non-conventional biomass (microalgae or glycerol) fall into this category. Using a wide variety of chemical additives like $\mathrm{NaOH}$, $\mathrm{Ca}(\mathrm{OH})_{2}, \mathrm{NH}_{4} \mathrm{OH}, \mathrm{H}_{3} \mathrm{PO}_{4}$, etc. can improve the biogas production yield. Using additives can improve the $\mathrm{AD}$ process stability and lead to up to $40 \%$ higher methane yield.

Recent research has been conducted using carbon membranes for biogas upgrading (Lie 2005) where the gas separation process was faster. The selected membranes were thin carbon layers with a thickness of less than $1 \mu \mathrm{m}$ supported on ceramic tubes with a length of $0.50 \mathrm{~m}$. Permeation tests using these membranes showed that the $\mathrm{CO}_{2}$ molecules permeate 50 times faster than $\mathrm{CH}_{4}$ molecules. By using such membranes, a typical gas mixture consisted of 0.6 of $\mathrm{CH}_{4}$ is enriched with $\mathrm{CH}_{4}$ by only one step separation process to more than 0.9 at $1.20 \mathrm{MPa}$. The membranes showed excellent mechanical properties after a one-month test. The same membranes are used to separate other gases in the biogas mixture such as $\mathrm{H}_{2} \mathrm{~S}$ gas. Such new technologies helped a lot in the biogas industrial process in terms of cost reduction and energy consumption compared to classical technologies such as scrubbing.

As mentioned in this part, process, pretreatment, and feedstock are the main influential parameters for biogas production. For obtaining the highest yield in this term, forming a proper balance between these factors has a significant impact on efficiency. Biomass comprises carbohydrate matters, proteins substances, fats, cellulose, and hemicellulose, which could be employed as raw materials for biogas production. In the existing method, co-substrates improved gas yield by increasing the organic content. Distinctive co-substrates contain organic wastes from agriculture-linked productions, food leftover, and gathered municipal wastes from houses. The composition and yield of biogas production be determined by the feedstock and co-substrate category. Although carbohydrates or proteins demonstrate quicker transformation degrees than fats, it is stated that the second one provides more biogas yield (Achinas et al. 2017; Braun 2007). To keep away from process non-fulfillments, pretreatment is essential. Employing pretreatment approaches improves the degradation of substrates and then the process productivity. Chemical, thermal, mechanical, or enzymatic procedures can be used to accelerate the decomposition method, while this doesn't unavoidably affect an advanced yield (Putatunda et al. 2020; Mshandete et al. 2006).

\section{Policy and framework conditions}

The biogas industry expands and develops as it represents an alternative source of energy and has a direct influence on the economy. Worldwide many countries organize the market of biogas through policies and regulations. Well-prepared policies prosper the market of biogas as a renewable energy source. 
For instance, by EU policies, instructions, and strategic planning, the portion of renewable energies from 2005 to 2015 increased from $9 \%$ up to $16.7 \%$, which is predicted to rise to $20 \%$ until 2020 (Irena 2018).

Keeping these long-term policies with continuous revision and evaluation is a leader in the world of biogas utilization and marketing (Al Seadi et al. 2000; Torrijos 2016).

Several organizations and governments such as the European Biogas Association (EBA) and the European Parliament and Council legislated regulations in this regard (Xue et al. 2020). The role of such organizations is to prepare new relevant policies for upcoming issues and update existing policies to satisfy the market needs and fluctuations and to harmonize the environment and investment. For example, in the UK there are 118 renewable energy policies compared to 7, 28, and 32 in Denmark, Italy, and German, respectively. This is a common framework, and it is used to write their national policies for organizing renewable energy in Europe. Despite the presence of common European directives such as (2009/28/EC) that considered the biogas production from of agronomic deposits and organic trashes and its application in producing power and heat, several EU nations established their energy markets and biomass sources. These countries issued policies to satisfy their own needs and priorities which known as the National Renewable Energy Action Plan.

China has more than 25 energy policies to manage renewable energy. These policies support the renewable market. Biogas was among these renewable energy sources that benefit from such policies and regulations to develop. The Chinese government governmental parties such as the State Council (SC), the Party Central Committee (PCC), and the Ministry of Agriculture and Rural Affairs (MARA) of China participated extensively in developing policies, regulations, and instruction relevant to the progress of biogas ( $\mathrm{Gu}$ et al. 2016; Hua et al. 2016; Wang et al. 2016b). There is a policy about the development necessities of biogas in rural zones that must be updated every year since 2004 it is called Central Document No. 1 (Ndrc 2017).

To point out some Chinese policies, the policy of Measures for the Administration of Rural Biogas Construction National Debt Projects (Trial) was developed in 2003 by its Ministry of Ecology and Environment (MEE) and Rural Biogas Project Construction Fund Management Measures was developed by both MARA and Ministry of Finance (MF) of China in 2007.

Recently in 2019 , there has been two policies that resulted in numerous ideas to follow the significant growth of farming and rustic zones, the experimental work program establishing waste-free cities by the state council (SC), and the friendly waste of rustic facilities of biogas production by (MARA). All of these policies regarding the handling, management, utilization, and safe disposal technologies are developed by many authorities in china to avoid the work duplication that might retard the international investment and privatization programs. Clear organization between different authorities helps in generating national priorities and smooth management this includes agricultural activities, finance, trade, and scientific research. For example, introducing a fixed premium subsidy enabled the development of biogas and green gas projects, where a finite budget for a subsidy was determined first. Another country introduced what so-called bioeconomy, especially for such projects. Finally, the harmonized sales tax (HST) is paid on purchases/expenses related to commercial construction and operation of biogas facilities which is also called (input tax credits).

\section{Policy framework}

It is important in any policy development to have certain targets to be achieved. These targets are dependent on national priorities, so it is changed from one country to another despite having common targets. Examples of targets can be achieving sustainable development for environment elements, communicate clear standards and regulations for wastes management, environmental laws to regulate the relevant processes and etc. To achieve these targets, action plans revised on a yearly basis to evaluate and update the current regulations for future use.

In general, there are five phases to develop a certain biogas policy, which are:

Phase I creating one regulatory body to coordinate the efforts of all stakeholders who can affect/ be affected by the activities of biogas management, by selecting one focal point to help in decision making and future development. This focal point can be from government or from non-governmental organizations (NGOs). This will unify the efforts to get national priorities and plans.

Phase II developing comprehensive and clear instructions and requirements for biogas production that includes management of raw materials, biogas, safe disposal of biogas wastes, preparing environmental impact assessment (EIA) for current and future facilities, applying the waste hierarchy which is referred to as 5Rs (responsibility, reduce, reuse, recycle, recover), issuing the license and permit to work, and applying the periodic environmental audit.

It is also important to apply the proximity principle for the newly constructed biogas plants and make sure to have a centralized biogas plant where all raw materials from different sources can reach it. The idea behind the one huge centralized biogas plant is to make the audit, monitoring, waste collection, transportation, packaging, labeling, storing and/or and safe disposal as easy as possible and make sure that the best and correct disposal method is applied, for 
example, in Denmark the Danish Government introduced a total ban on landfilling organic or combustible wastes in 1997 (Al seadi T. 2017).

Phase III providing incentives and subsidizing to encourage the facilities to produce biogas and increase its contribution to the economy which is referred to as the green economy and to encourage the partnership with the private sector. Such a program will help the facilities that deal with biogas in rehabilitation activities and waste management. Such incentives and subsidy include tax-free period, free consultation, reduced tariff for raw materials used in the manufacturing procedure, and decrease in the payback period increasing the return on investment of the coming projects which in turn will help in mitigation the biogas sustainability challenges. Contingency plans for unexpected challenges must be considered. The sectors of energy and renewable energy are exposed to many parameters that can affect the energy market such as wars, natural disasters, and nowadays the pandemic of COVID-19 where the prices of oil are dropped drastically (Hübner and Mumme 2015) and negative effects are imposed on the industry.

Phase IV providing scientific support to the projects of biogas and waste-to-energy plants. This is necessary to use the best environmental practices (BEP) and the best available techniques (BAT). This can be achieved by technology transfer and scientific research, where each plant must have a research and development (RD) department. Ministry of higher education or any relevant authority in the countries with cooperation with industry can provide funds to universities and plants for more research to utilize the waste in producing energy.

Phase VI participating in international conventions and agreements. Each country must participate in international activities and international conventions relevant to waste management and W-t- E initiatives such as Basel conventions (Basel, 2020) that regulate the transboundary movements of hazardous wastes. This participation is important to make use from the experience of each other and to get the consultation from international experts and to get fund for environmental projects from international agencies such as the German Technical Cooperation Agency (GTZ), Japan International Cooperation Agency (JICA), and United States Agency for International Development (USAID),

Phase VII training and awareness programs, where the concerned parties of W-to-E activities prepare training programs for its staff in the fields of waste management, national and international laws, environmental auditing, risk assessment/management, inspection and licensing. Also, the awareness program for the public is important to educate the people in cleaner production and relevant environmental issues. The role of universities is also important to introduce courses for undergraduate and postgraduate students to raise awareness and support scientific research.

\section{Conclusion and recommendation}

With the new applications of biogas, the worldwide biogas industry has increased by more than $90 \%$ between the years 2010 and 2018, while further growth is still expected. However, the biogas industry varies significantly in different locations over all the world. Different countries have developed several types of biogas systems which are mainly dependent on different environments as well as on energy demand and supply chain. In this study, the production processes and specific applications of biogas in recent years were reviewed and discussed. In the lack of oxygen, the disintegration of organic material produces biogas that mostly consists of carbon dioxide and methane. In recent years, the exploitation of biogas and the expansion of its potential applications have gained popularity due to factors like climate change, reasonable energy prices, and an increase in distributed generation. Biogas also traditionally known as an off-grid energy resource and can be used in various applications consisting of electricity production and CHP systems. The following key points are summarized from the study:

- It is envisioned that the extraction of intrinsic chemical energy of biomass with an efficient AD process can be achieved with proper microbial resource management. Further, advanced monitoring and control of the AD process are needed for the hour for decision making to improve the conversion productivity of the procedure by decreasing the loss of potential methane production due to imbalances of biomass charging rate.

- A sustainable circular economy can be created through biomass utilization by recycling organic residues including nutrients in order to bring it back to the society as energy and fuel.

- Upgradation of the existing technology for efficient conversion of biomass-based organic residues to biomethane and its utilization as a substitute natural gas or vehicle fuel is the trending research scope.

- Hydrogen production using a biogas reforming system with high efficiency is one of the recent applications of biogas. The progress in the application of hydrogen as a clean fuel especially for vehicles is very promising.

- Another cutting-edge application of biogas is fuel cells. Recent advances in fuel cells resulting in low emissions $\left(\mathrm{CO}_{2}, \mathrm{NO}_{\mathrm{x}}\right)$ and high efficiency make them suitable for power generation and transportation purposes.

- Even though the conversion of biomass to biogas through $\mathrm{AD}$ has already become a touchable reality in many countries, high financial risks linked to its establishment seek higher financial incentives from the policymakers for sustainable shifting of existing technologies. 
Failure of the extraction/utilization of renewable energy sources does not sanction the researchers to explore further, but to transfer any sustainable technology from laboratory to the market seeks ground-breaking effort of the researchers and incentives from the policymakers to handle wisely the transition period of partial/full replacement(s)/ modification(s) of the existing technologies/infrastructures, and social acceptance of the simplified - and perhaps definitive-application of the renewables.

Acknowledgements No financial support exists in this paper.

\section{References}

Abbasi T, Tauseef S, Abbasi SA (2012) Biogas energy. Springer, New York

Abdeshahian P, Lim JS, Ho WS, Hashim H, Lee CT (2016) Potential of biogas production from farm animal waste in Malaysia. Renew Sustain Energy Rev 60:714-723

Abelleira-Pereira JM, Pérez-Elvira SI, Sánchez-Oneto J, de la Cruz R, Portela JR, Nebot E (2015) Enhancement of methane production in mesophilic anaerobic digestion of secondary sewage sludge by advanced thermal hydrolysis pretreatment. Water Res 71:330-340

Abouelenien F, Fujiwara W, Namba Y, Kosseva M, Nishio N, Nakashimada Y (2010) Improved methane fermentation of chicken manure via ammonia removal by biogas recycle. Biores Technol 101(16):6368-6373

Achinas S, Achinas V, Euverink GJW (2017) A technological overview of biogas production from biowaste. Engineering 3(3):299-307

Agency DE. (2019) Biogas in Denmark

Agency IRE. IRENA (2019), Renewable Energy Statistics 2019

Ahmadi A, Esmaeilion F, Esmaeilion A, Ehyaei MA, Silveira J (2020) Benefits and limitations of waste-to-energy conversion in Iran. Renew Energy Res Appl 1(1):27-45

Ahn S, You Y-W, Lee D-G, Kim K-H, Oh M, Lee C-H (2012) Layered two- and four-bed PSA processes for $\mathrm{H} 2$ recovery from coal gas. Chem Eng Sci 68:413-23

Al Seadi T, Hjort-Gregersen K, Holm-Nielsen J. (2000) The impact of the Legislative Framework on the Implementation and Development of Manure Based Centralised Co-digestion Systems in Denmark. University of Southern Denmark

Al seadi T. (2017) Denmark - Country Report. IEA Bioenergy Task 37 'Energy from biogas'. Biosantech. 2017

Alves HJ, Junior CB, Niklevicz RR, Frigo EP, Frigo MS, CoimbraAraújo CH (2013) Overview of hydrogen production technologies from biogas and the applications in fuel cells. Int J Hydrog Energy 38(13):5215-25

Alves HJ, Junior CB, Niklevicz RR, Frigo EP, Frigo MS, CoimbraAraújo CH (2013) Overview of hydrogen production technologies from biogas and the applications in fuel cells. Iran J Hydrog Energy 38:5215-25

Angelidaki I, Treu L, Tsapekos P, Luo G, Campanaro S, Wenzel H et al (2018) Biogas upgrading and utilization: current status and perspectives. Biotechnol Adv 36(2):452-466

Antoine Beylot SM, Descat M, Ménard Y, Villeneuve J (2018) Life cycle assessment of the French municipal solid waste incineration sector. Waste Manag 80:144-53

Ariunbaatar J, Panico A, Esposito G, Pirozzi F, Lens PN (2014) Pretreatment methods to enhance anaerobic digestion of organic solid waste. Appl Energy 123:143-156
Armor JN (1999) The multiple roles for catalysis in the production of H2. Appl Catal A 176(2):159-176

Association EB. (2018) EBA Statistical Report 2018

Association WB. (2018) International Market Report, USA

Association WB. Canada Market Report. 2019.

Association CB. (2019) Biogas Potential

Association WB. (2019) Global potential of biogas

Association ADaB. (2018) ADBA annual report 2019

Atelge MR, Krisa D, Kumar G, Eskicioglu C, Nguyen DD, Chang SW, Atabani AE, Al-Muhtaseb AH, Unalan S (2018) Biogas production from organic waste: recent progress and perspectives. Waste Biomass Valoriz 11:1019-40

Australia B. (2019) Biogas opportunities for Australia

Azman S, Khadem AF, Van Lier JB, Zeeman G, Plugge CM (2015) Presence and role of anaerobic hydrolytic microbes in conversion of lignocellulosic biomass for biogas production. Crit Rev Environ Sci Technol 45(23):2523-2564

Backman M, Rogulska M (2016) Biomethane use in Sweden. Archiwum Motoryzacji 71(1):7-19

Badshah M, Lam DM, Liu J, Mattiasson B (2012) Use of an automatic methane potential test system for evaluating the biomethane potential of sugarcane bagasse after different treatments. Biores Technol 114:262-269

Bao H, Jiang L, Chen C, Yang C, He Z, Feng Y et al (2015) Combination of ultrasound and Fenton treatment for improving the hydrolysis and acidification of waste activated sludge. RSC Adv 5(60):48468-48473

Bassani I, Kougias PG, Angelidaki I (2016) In-situ biogas upgrading in thermophilic granular UASB reactor: key factors affecting the hydrogen mass transfer rate. Biores Technol 221:485-491

Bauer A, Lizasoain J, Theuretzbacher F, Agger JW, Rincón M, Menardo S et al (2014) Steam explosion pretreatment for enhancing biogas production of late harvested hay. Biores Technol 166:403-410

Bentayeb M, Simoni M, Norback D, Baldacci S, Maio S, Viegi G et al (2013) Indoor air pollution and respiratory health in the elderly. J Environ Sci Health, Part A 48(14):1783-1789

Bioenergy IEAI. (2019) Austaralia Country Report

Bioenergy IEAI. (2019) The Netherlands Country Report -2019

Bioenergy IEAI. (2019) Denmark Country Report -2019

Bioenergy IEAI. (2019) Country Report Summaries 2019

Bioenergy IEAI. (2019) Country Report Sweden, 2019

Biswas AK, Umeki K, Yang W, Blasiak W (2011) Change of pyrolysis characteristics and structure of woody biomass due to steam explosion pretreatment. Fuel Process Technol 92(10):1849-1854

Blonskaja V, Menert A, Vilu R (2003) Use of two-stage anaerobic treatment for distillery waste. Adv Environ Res 7(3):671-678

Bochmann G, Montgomery LFR (2013) Storage and pre-treatment of substrates for biogas production. In: Wellinger A, Murphy $\mathrm{J}$, Baxter D (eds) The biogas handbook: science, production and applications. Woodhead Publishing, Oxford

Bolzonella D, Cavinato C, Fatone F, Pavan P, Cecchi F (2012) High rate mesophilic, thermophilic, and temperature phased anaerobic digestion of waste activated sludge: a pilot scale study. Waste Manag 32(6):1196-1201

BP (2019) Statistical review of world energy. British Petroleum, UK

Branchini L (2015) Waste-to-energy: advanced cycles and new design concepts for efficient power plants. Springer, Berlin

Braun R (2007) Anaerobic digestion: a multi-faceted process for energy environmental management and rural development. In: Ranalli P (ed) Improvement of crop plants for industrial end uses. Springer, Berlin, pp 335-416

Bridgwater AV (2012) Review of fast pyrolysis of biomass and product upgrading. Biomass Bioenergy 38:68-94

Canada NR. (2019) Renewable Energy Facts 
Cara C, Ruiz E, Ballesteros I, Negro MJ, Castro E (2006) Enhanced enzymatic hydrolysis of olive tree wood by steam explosion and alkaline peroxide delignification. Process Biochem 41(2):423-429

Carvajal A, Peña M, Pérez-Elvira S (2013) Autohydrolysis pretreatment of secondary sludge for anaerobic digestion. Biochem Eng J 75:21-31

Cella MA, Akgul D, Eskicioglu C (2016) Assessment of microbial viability in municipal sludge following ultrasound and microwave pretreatments and resulting impacts on the efficiency of anaerobic sludge digestion. Appl Microbiol Biotechnol 100(6):2855-2868

Chan MT, Selvam A, Wong JW (2016) Reducing nitrogen loss and salinity during 'struvite' food waste composting by zeolite amendment. Biores Technol 200:838-844

Chandra RP, Bura R, Mabee W, Berlin DA, Pan X, Saddler J (2007) Substrate pretreatment: the key to effective enzymatic hydrolysis of lignocellulosics? In: Olsson L (ed) Biofuels. Springer, Berlin, pp 67-93

Chandra R, Takeuchi H, Hasegawa T, Kumar R (2012) Improving biodegradability and biogas production of wheat straw substrates using sodium hydroxide and hydrothermal pretreatments. Energy 43(1):273-282

Chen L, Zhao L, Ren C, Wang F (2012) The progress and prospects of rural biogas production in China. Energy Policy 51:58-63

Chen C, Guo W, Ngo HH, Lee D-J, Tung K-L, Jin P et al (2016) Challenges in biogas production from anaerobic membrane bioreactors. Renew Energy 98:120-134

Colussi I, Cortesi A, Gallo V, Rubesa Fernandez A, Vitanza R (2013) Improvement of methane yield from maize silage by a twostage anaerobic process. Chem Eng Trans 32(1):151-156

Council AB. (2019) Operational U.S. Biogas system

Council AB. (2019) California biogas state profile

Council AB. (2019) Texas biogas state profile

Damyanova S, Beschkov V (2020) Biogas as a source of energy and chemicals. In: Beschkov V (ed) Biorefinery concepts. IntechOpen

de Arespacochaga N, Valderrama C, Peregrina C, Mesa C, Bouchy L, Cortina JL (2015) Evaluation of a pilot-scale sewage biogas powered $14472.8 \mathrm{~kW}$ e solid oxide fuel cell: assessment of heatto-power ratio and influence of oxygen content. J Power Sour 300:325-35

Demirel B, Scherer P (2011) Trace element requirements of agricultural biogas digesters during biological conversion of renewable biomass to methane. Biomass Bioenerg 35(3):992-998

Dieter Deublein AS (2008) Biogas from waste and renewable resources, an introduction. Wiley-VCH, Germany

Doan Pham Minh TJS, Vo D-VN, Phan TS, Ridart C, Nzihou A, Grouset D (2018) Hydrogen production from biogas reforming: an overview of steam reforming, dry reforming, dual reforming, and tri-reforming of methane. In: Azzaro-Pantel C (ed) Hydrogen supply chain. Elsevier

Dohányos M, Zábranská J, Jenícek P (1997) Enhancement of sludge anaerobic digestion by using of a special thickening centrifuge. Water Sci Technol 36(11):145-153

Edenhofer O, Pichs-Madruga R, Sokona Y, Seyboth K, Kadner S, Zwickel $\mathrm{T}$ et al (2011) Renewable energy sources and climate change mitigation: special report of the intergovernmental panel on climate change. Cambridge University Press, Cambridge

Esmaeilion F, Ahmadi A, Dashti R (2021) Exergy-economic-environment optimization of the waste-to-energy power plant using multi-objective particle-swarm optimization (MOPSO). Scientia Iranica 3(2):42

Eurostat. (2019) European Statistics

Faaij A (2006) Modern biomass conversion technologies. Mitig Adapt Strat Glob Change 11(2):343-375
Feng X, Deng J, Lei H, Bai T, Fan Q, Li Z (2009) Dewaterability of waste activated sludge with ultrasound conditioning. Biores Technol 100(3):1074-1081

Ferreira S, Monteiro E, Brito P, Vilarinho C (2017) Biomass resources in Portugal: current status and prospects. Renew Sustain Energy Rev 78:1221-1235

Ghasemian S, Faridzad A, Abbaszadeh P, Taklif A, Ghasemi A, Hafezi R (2020) An overview of global energy scenarios by 2040: identifying the driving forces using cross-impact analysis method. Int J Environ Sci Technol. https://doi.org/10.1007/ s13762-020-02738-5

Ginting N (2020) The effect of bioctivator addition to the quality of bio gas slurry. E\&ES 454(1):012069

Gioele Di Marcoberardino DV, Spinelli F, Marco Binotti ID, Manzolini G (2018) Green hydrogen production from raw biogas: a technoeconomic investigation of conventional processes using pressure swing adsorption unit. Processes 6:19

Government of Nepal Ministry of Energy WRaI. (2020) Biogas

Gu L, Zhang Y-X, Wang J-Z, Chen G, Battye H (2016) Where is the future of China's biogas? Review, forecast, and policy implications. Pet Sci 13(3):604-624

Guiot SR, Cimpoia R, Carayon G (2011) Potential of wastewatertreating anaerobic granules for biomethanation of synthesis gas. Environ Sci Technol 45(5):2006-2012

Hagos K, Zong J, Li D, Liu C, Lu X (2017) Anaerobic co-digestion process for biogas production: Progress, challenges and perspectives. Renew Sustain Energy Rev 76:1485-1496

He Y, Bagley DM, Leung KT, Liss SN, Liao B-Q (2012) Recent advances in membrane technologies for biorefining and bioenergy production. Biotechnol Adv 30(4):817-858

Hendriks A, Zeeman G (2009) Pretreatments to enhance the digestibility of lignocellulosic biomass. Biores Technol 100(1):10-18

Herbes C, Halbherr V, Braun L (2018) Factors influencing prices for heat from biogas plants. Appl Energy 221:308-318

Holladay JD, Hu J, King DL, Wang Y (2009) An overview of hydrogen production technologies. Catal Today 139:244-60

Horváth IS, Tabatabaei M, Karimi K, Kumar R (2016) Recent updates on biogas production-a review. Biofuel Res J 10:394-402

Hua Y, Oliphant M, Hu EJ (2016) Development of renewable energy in Australia and China: a comparison of policies and status. Renew Energy 85:1044-1051

Hübner T, Mumme J (2015) Integration of pyrolysis and anaerobic digestion-use of aqueous liquor from digestate pyrolysis for biogas production. Biores Technol 183:86-92

IRENA E. (2018) Renewable energy prospects for the European Union. International Renewable Energy Agency (IRENA), European Commission (EC), Abu Dhabi

IRENA RES. International Renewable Energy Agency. (2015) Renewable energy target setting, Abu Dhabi, UAE

Jiang X, Sommer SG, Christensen KV (2011) A review of the biogas industry in China. Energy Policy 39(10):6073-6081

Kalia A, Singh S (2004) Development of a biogas plant. Energy Sour 26(8):707-714

Kaparaju P, Rintala J (2013) 17-Generation of heat and power from biogas for stationary applications: boilers, gas engines and turbines, combined heat and power (CHP) plants and fuel cells. In: Wellinger A, Murphy J, Baxter D (eds) The biogas handbook. Woodhead Publishing, pp 404-27

Kaparaju P, Serrano M, Thomsen AB, Kongjan P, Angelidaki I (2009) Bioethanol, biohydrogen and biogas production from wheat straw in a biorefinery concept. Biores Technol 100(9):2562-2568

Kapoor R, Ghosh P, Kumar M, Vijay VK (2019) Evaluation of biogas upgrading technologies and future perspectives: a review. Environ Sci Pollut Res 26(12):11631-11661

Kemausuor F, Adaramola M, Morken J (2018) A review of commercial biogas systems and lessons for Africa. Energies 11:2984 
Kim J, Novak JT, Higgins MJ (2011) Multistaged anaerobic sludge digestion processes. J Environ Eng 137(8):746-753

Kolesárová N, Hutňan M, Bodík I, Špalková V. (2011) Utilization of biodiesel by-products for biogas production. BioMed Res Int 2011

Kuttner P, Weißböck A, Leitner V, Jäger A (2015) Examination of commercial additives for biogas production. Agron Res 13(2):337-347

Lampinen A (2015) Quality of renewable energy utilization in transport in Sweden. Strömstad Akademi

Laser M, Schulman D, Allen SG, Lichwa J, Antal MJ Jr, Lynd LR (2002) A comparison of liquid hot water and steam pretreatments of sugar cane bagasse for bioconversion to ethanol. Biores Technol 81(1):33-44

Lebuhn M, Munk B, Effenberger M (2014) Agricultural biogas production in Germany-from practice to microbiology basics. Energy, Sustain Soc 4(1): 10

Lemmer A, Chen Y, Wonneberger A-M, Graf F, Reimert R (2015) Integration of a water scrubbing technique and two-stage pressurized anaerobic digestion in one process. Energies 8(3):2048-2065

Li C, Wang X, Zhang G, Yu G, Lin J, Wang Y (2017) Hydrothermal and alkaline hydrothermal pretreatments plus anaerobic digestion of sewage sludge for dewatering and biogas production: benchscale research and pilot-scale verification. Water Res 117:49-57

Li Y, Su D, Luo S, Jiang H, Qian M, Zhou H et al (2017) Pyrolysis gas as a carbon source for biogas production via anaerobic digestion. RSC Adv 7(66):41889-41895

Li C, Wang X, Zhang G, Li J, Li Z, Yu G et al (2018) A process combining hydrothermal pretreatment, anaerobic digestion and pyrolysis for sewage sludge dewatering and co-production of biogas and biochar: pilot-scale verification. Bioresour Technol 254:187-193

Liao B, Xie K, Lin H, Bertoldo D (2010) Treatment of kraft evaporator condensate using a thermophilic submerged anaerobic membrane bioreactor. Water Sci Technol 61(9):2177-2183

Lie JA (2005) Synthesis, performance and regeneration of carbon membranes for biogas upgrading - a future energy carrier. Department of Chemical Engineering Norwegian University of Science and technology, Trondheim

Liu Y, Li X, Kang X, Yuan Y, Jiao M, Zhan J et al (2015) Effect of extracellular polymeric substances disintegration by ultrasonic pretreatment on waste activated sludge acidification. Int Biodeterior Biodegrad 102:131-136

Liu X, Xu Q, Wang D, Zhao J, Wu Y, Liu Y et al (2018) Improved methane production from waste activated sludge by combining free ammonia with heat pretreatment: performance, mechanisms and applications. Biores Technol 268:230-236

Luca A, Cossu R (2015) Composition variability of the organic fraction of municipal solid waste and effects on hydrogen and methane production potentials. Waste Manag 36:147-55

Luo Y, Guda V, Wijayapala R, Steele PH (2016) Upgrading of syngas hydrotreated fractionated oxidized bio-oil to transportation grade hydrocarbons. Energy Convers Manag 115:159-166

Mafu LD, Neomagus HW, Everson RC, Carrier M, Strydom CA, Bunt JR (2016) Structural and chemical modifications of typical South African biomasses during torrefaction. Biores Technol 202:192-197

Mao C, Feng Y, Wang X, Ren G (2015) Review on research achievements of biogas from anaerobic digestion. Renew Sustain Energy Rev 45:540-555

Maurer C, Müller J (2019) Drying characteristics of biogas digestate in a hybrid waste-heat/solar dryer. Energies 12(7):1294

McCabe BK, Schmidt T (2018) Integrated biogas systems: local applications of anaerobic digestion towards integrated sustainable solutions. Technical Report, IEA Bioenergy
Micolucci F, Gottardo M, Cavinato C, Pavan P, Bolzonella D (2016) Mesophilic and thermophilic anaerobic digestion of the liquid fraction of pressed biowaste for high energy yields recovery. Waste Manag 48:227-235

Milbrandt GSaA. (2018) Renewable hydrogen potential from biogas in the United States. USA: National Renewable Energy Laboratory.

Miltner M, Makaruk A, Harasek M (2017) Review on available biogas upgrading technologies and innovations towards advanced solutions. J Clean Prod 161:1329-1337

Minardi ER, Chakraborty S, Calabro V, Curcio S, Drioli E (2015) Membrane applications for biogas production and purification processes: an overview on a smart alternative for process intensification. RSC Adv 5(19):14156-14186

Mirmasoumi S, Ebrahimi S, Saray RK (2018) Enhancement of biogas production from sewage sludge in a wastewater treatment plant: evaluation of pretreatment techniques and co-digestion under mesophilic and thermophilic conditions. Energy 157:707-717

Mittal S, Ahlgren EO, Shukla PR (2019) Future biogas resource potential in India: a bottom-up analysis. Renew Energy 141:379-389

MNER. Annual Report 2016/2017 in India. In: Ministry of New and Renewable Energy GoI, editor. India2017.

Montgomery LF, Bochmann G (2014) Pretreatment of feedstock for enhanced biogas production. IEA Bioenergy Ireland

Mshandete A, Björnsson L, Kivaisi AK, Rubindamayugi MS, Mattiasson B (2006) Effect of particle size on biogas yield from sisal fibre waste. Renew Energy 31(14):2385-2392

Muche T, Höge C, Renner O, Pohl R (2016) Profitability of participation in control reserve market for biomass-fueled combined heat and power plants. Renew Energy 90:62-76

Mutungwazi A, Mukumba P, Makaka G (2018) Biogas digester types installed in South Africa: a review. Renew Sustain Energy Rev $81: 172-180$

NDRC M. (2015) Working plan of upgrading and transforming rural biogas project. Beijing, China: National Development and Reform Commission (NDRC) and Ministry of Agriculture (MOA)

Ndrc M. (2017) National 13th five-year plan for rural biogas development. Ministry of Agriculture and Rural Affairs, National Development and Reform Commission of the People's Republic of China; 2017. https://policy.asiapacificenergy.org/node/3041 [in Chinese], [accessed 14, June, 2020]

Nicolae Scarlat J-FD, Fahl F (2018) Biogas: developments and perspectives in Europe. Renew Energy 129:457-72

Nikpey Somehsaraei H, Mansouri Majoumerd M, Breuhaus P, Assadi M (2014) Performance analysis of a biogas-fueled micro gas turbine using a validated thermodynamic model. Appl Therm Eng 66(1):181-190

Olofsson K, Bertilsson M, Lidén G (2008) A short review on SSF-an interesting process option for ethanol production from lignocellulosic feedstocks. Biotechnol Biofuels 1(1):7

Parawira W (2009) Biogas technology in sub-Saharan Africa: status, prospects and constraints. Rev Environ Sci Bio/Technol 8:187-200

Park Y, Hong F, Cheon J, Hidaka T, Tsuno H (2008) Comparison of thermophilic anaerobic digestion characteristics between singlephase and two-phase systems for kitchen garbage treatment. J Biosci Bioeng 105(1):48-54

Park S, Yoon Y-M, Han SK, Kim D, Kim H (2017) Effect of hydrothermal pre-treatment (HTP) on poultry slaughterhouse waste (PSW) sludge for the enhancement of the solubilization, physical properties, and biogas production through anaerobic digestion. Waste Manag 64:327-332

Pawlita-Posmyk M, Wzorek M (2018) Assessing the possible use of selected types of rural waste in biogas production. Intercathedra 36(3):283-289 
Pecorini I, Baldi F, Carnevale EA, Corti A (2016) Biochemical methane potential tests of different autoclaved and microwaved lignocellulosic organic fractions of municipal solid waste. Waste Manag 56:143-150

Pérez CM, Weber A (2013) Two stage anaerobic digestion system: hydrolysis of different substrate. Landtechnik 68(4):252-255

Pöschl M, Ward S, Owende P (2010) Evaluation of energy efficiency of various biogas production and utilization pathways. Appl Energy 87(11):3305-3321

Prasad S, Rathore D, Singh A (2017) Recent advances in biogas production. Chem Engin Process Tech 3(2): 1038

Putatunda C, Walia A, Sharma R, Solanki P (2020) Current trends and aspects of microbiological biogas production. In: Singh J, Vyas A, Wang S, Prasad R (eds) Microbial biotechnology: basic research and applications. Springer, Singapore, pp 265-97

Rachbauer L, Voitl G, Bochmann G, Fuchs W (2016) Biological biogas upgrading capacity of a hydrogenotrophic community in a trickle-bed reactor. Appl Energy 180:483-490

Rodriguez C, Alaswad A, Benyounis K, Olabi AG (2017) Pretreatment techniques used in biogas production from grass. Renew Sustain Energy Rev 68:1193-1204

Ruiz-Hernando M, Cabanillas E, Labanda J, Llorens J (2015) Ultrasound, thermal and alkali treatments affect extracellular polymeric substances (EPSs) and improve waste activated sludge dewatering. Process Biochem 50(3):438-446

Rümmeli MH, Schäffel F, Bachmatiuk A, Adebimpe D, Trotter G, Börrnert $\mathrm{F}$ et al (2010) Investigating the outskirts of $\mathrm{Fe}$ and $\mathrm{Co}$ catalyst particles in alumina-supported catalytic CVD carbon nanotube growth. ACS Nano 4(2):1146-1152

Ryckebosch E, Drouillon M, Vervaeren H (2011) Techniques for transformation of biogas to biomethane. Biomass Bioenerg 35(5):1633-1645

Saadabadi SA, Thattai AT, Fan L, Lindeboom RE, Spanjers H, Aravind P (2019) Solid oxide fuel cells fuelled with biogas: potential and constraints. Renew Energy 134:194-214

Saadabadi SA, Thattai AT, Liyuan F, Lindeboom REF, Spanjers H, Aravind PV (2019) Solid oxide fuel cells fuelled with biogas: potential and constraints. Renew Energy 134:194-214

Safari S, Hajilounezhad T, Ehyaei MA (2020) Multi-objective optimization of solid oxide fuel cell/gas turbine combined heat and power system: a comparison between particle swarm and genetic algorithms. Int J Energy Res 44(11):9001-9020

Safari S, Ghasedi AH, Ozgoli HA. (2020) Integration of solar dryer with a hybrid system of gasifier-solid oxide fuel cell/micro gas turbine: energy, economy, and environmental analysis. Environ Prog \& Sustain Energy n/a(n/a):e13569

Sarkar M, Kumar A, Tumuluru JS, Patil KN, Bellmer DD (2014) Gasification performance of switchgrass pretreated with torrefaction and densification. Appl Energy 127:194-201

Sarker S, Lamb JJ, Hjelme DR, Lien KM (2018) Overview of recent progress towards in-situ biogas upgradation techniques. Fuel 226:686-697

Scarlat N, Dallemand J-F, Fahl F (2018) Biogas: developments and perspectives in Europe. Renew Energy 129:457-472

Seadi TAL, J. (2019) Country Report Denmark, IEA Bioenergy Task 37: Paris. France

Shahriari H, Warith M, Hamoda M, Kennedy KJ (2012) Anaerobic digestion of organic fraction of municipal solid waste combining two pretreatment modalities, high temperature microwave and hydrogen peroxide. Waste Manag 32(1):41-52

Shipley A, Hampson A, Hedman B, Garland P, Bautista P. (2009) DOE report: combined heat and power: effective energy solutions for a sustainable future

Song Z, Zhang C, Yang G, Feng Y, Ren G, Han X (2014) Comparison of biogas development from households and medium and large-scale biogas plants in rural China. Renew Sustain Energy Rev 33:204-13

Spyridon A, Euverink W, Jan G (2016) Consolidated briefing of biochemical ethanol production from lignocellulosic biomass. Electron J Biotechnol 19(5):44-53

Sreekrishnan T, Kohli S, Rana V (2004) Enhancement of biogas production from solid substrates using different techniques-a review. Biores Technol 95(1):1-10

Statistics NBo. (2018) China Rural Statistical Yearbook. Beijing, China: China Statistics Press

Steubing B, Zah R, Waeger P, Ludwig C (2010) Bioenergy in Switzerland: assessing the domestic sustainable biomass potential. Renew Sustain Energy Rev 14(8):2256-2265

Stucki M, Jungbluth N, Leuenberger M. (2011) Life cycle assessment of biogas production from different substrates. Final report Bern: Federal Department of Environment, Transport, Energy and Communications, Federal Office of Energy

Sumphanwanich J, Leepipatpiboon N, Srinorakutara T, Akaracharanya A (2008) Evaluation of dilute-acid pretreated bagasse, corn cob and rice straw for ethanol fermentation by Saccharomyces cerevisiae. Ann Microbiol 58(2):219-225

Taherzadeh MJ, Karimi K (2008) Pretreatment of lignocellulosic wastes to improve ethanol and biogas production: a review. Int $\mathbf{J}$ Mol Sci 9(9):1621-1651

Teodorita Al Seadi DR, Prassl H, Köttner M, Finsterwalder T, Volk S, Janssen R (2008) Biogas handbook. University of Southern Denmark, Esbjerg

Tonrangklang P, Therdyothin A, Preechawuttipong I (2017) Overview of biogas production potential from industry sector to produce compressed bio-methane gas in Thailand. Energy Procedia 138:919-924

Torres ML, Lloréns MCE (2008) Effect of alkaline pretreatment on anaerobic digestion of solid wastes. Waste Manag 28(11):2229-34

Torrijos M (2016) State of development of biogas production in Europe. Procedia Environ Sci 35:881-889

Trendewicz A, Braun RJ (2013) Techno-economic analysis of solid oxide fuel cell-based combined heat and power systems for biogas utilization at wastewater treatment facilities. J Power Sour 233:380-93

Ugarte P, Duran P, Lasobras J, Soler J, Menéndez M, Herguido J (2017) Dry reforming of biogas in fluidized bed: process intensification. Iran J Hydrog Energy 42:13589-97

Union IG. (2015) Biogas from refuse to energy, Technical Report. IEA Bioenergy

Vervaeren H, Hostyn K, Ghekiere G, Willems B (2010) Biological ensilage additives as pretreatment for maize to increase the biogas production. Renew Energy 35(9):2089-2093

Visvanathan C, Abeynayaka A (2012) Developments and future potentials of anaerobic membrane bioreactors (AnMBRs). Membr Water Treat 3(1):1-23

Wang AJ, Li WW, Yu HQ (2011) Advances in Biogas Technology. In: Bai FW, Liu CG, Huang H, Tsao G (eds) Biotechnology in China III: biofuels and bioenergy, Advances in biochemical engineering biotechnology, vol 128. Springer, Berlin, Heidelberg. https://doi. org/10.1007/10_2011_126

Wang Q, Jiang G, Ye L, Yuan Z (2014) Enhancing methane production from waste activated sludge using combined free nitrous acid and heat pre-treatment. Water Res 63:71-80

Wang F, Zhang D, Wu H, Yi W, Fu P, Li Y et al (2016) Enhancing biogas production of corn stover by fast pyrolysis pretreatment. Biores Technol 218:731-736

Wang C, Zhang Y, Zhang L, Pang M (2016) Alternative policies to subsidize rural household biogas digesters. Energy Policy 93:187-195 
Wasajja H, Lindeboom RE, van Lier JB, Aravind P (2020) Technoeconomic review of biogas cleaning technologies for small scale off-grid solid oxide fuel cell applications. Fuel Process Technol 197:106215

Weiland P (2010) Biogas production: current state and perspectives. Appl Microbiol Biotechnol 85(4):849-860

Wongchanapai S, Iwai H, Saito M, Yoshida H (2013) Performance evaluation of a direct-biogas solid oxide fuel cell-micro gas turbine (SOFC-MGT) hybrid combined heat and power (CHP) system. J Power Sour 223:9-17

Wu Y-M, Zhao Z-1, Li H-B, Fang H (2009) Low temperature pyrolysis characteristics of major components of biomass. J Fuel Chem Technol 37(4):427-32

Wu N, Moreira C, Zhang Y, Doan N, Yang S, Phlips E, et al. (2019) Techno-economic analysis of biogas production from microalgae through anaerobic digestion. Biogas, review chapter

Xue S, Song J, Wang X, Shang Z, Sheng C, Li C et al (2020) A systematic comparison of biogas development and related policies between China and Europe and corresponding insights. Renew Sustain Energy Rev 117:109474

Yabu H, Sakai C, Fujiwara T, Nishio N, Nakashimada Y (2011) Thermophilic two-stage dry anaerobic digestion of model garbage with ammonia stripping. J Biosci Bioeng 111(3):312-319

Yang L, Ge X, Wan C, Yu F, Li Y (2014) Progress and perspectives in converting biogas to transportation fuels. Renew Sustain Energy Rev 40:1133-1152
Ylitervo P, Akinbomi J, Taherzadeh MJ (2013) Membrane bioreactors' potential for ethanol and biogas production: a review. Environ Technol 34(13-14):1711-1723

Yu L, Ma J, Frear C, Zaher U, Chen S. (2017) Two-stage anaerobic digestion systems wherein one of the stages comprises a twophase system. Google Patents

Zhao J. Enhancement of methane production from solid-state anaerobic digestion of yard trimmings by biological pretreatment: The Ohio State University, 2013.

Zhen G, Lu X, Kato H, Zhao Y, Li Y-Y (2017) Overview of pretreatment strategies for enhancing sewage sludge disintegration and subsequent anaerobic digestion: current advances, full-scale application and future perspectives. Renew Sustain Energy Rev 69:559-577

Zheng Y, Zhao J, Xu F, Li Y (2014) Pretreatment of lignocellulosic biomass for enhanced biogas production. Prog Energy Combust Sci 42:35-53

Zheng L, Chen J, Zhao M, Cheng S, Wang L-P, Mang H-P, Li Z (2020) What could China give to and take from other countries in terms of the development of the biogas industry? Sustainability 12(1490):1-21 